\title{
«Este es el libro de cómmo se deben pagar las debdas para quitar la eglesia» de Cuenca del entredicho pronunciado por el papa Juan XXII
}

\author{
F. ANTONIO ChACÓN*
}

\begin{abstract}
RESUMEN
Durante los meses de noviembre de
\end{abstract} 1329 a febrero del siguiente año, el

Cabildo de Cuenca se reunió frecuentemente para tratar de conseguir cierta cantidad de maravedís reclamados por la Curia aviñonense de las rentas generadas durante los más de dos años que había permanecido vacante su

Sede después de la muerte del obispo don Pascual, ocurrida en febrero de

1320, y cuya morosidad les había conducido al estado de «entredicho" pronunciado por el papa Juan XXII.

Dichas sesiones capitulares se recogieron en un "libro" que, rubricado por los canónigos y sellado con el sello de la institución capitular, se conserva en el archivo de la catedral conquense, siendo objeto de estudio desde la triple faceta codicológica, paleográfica y diplomática, precedido de unas breves notas que tienen como fin encuadrarlo en el momento histórico que vivía la Iglesia y que había conducido al Cabildo a la mencionada situación canónica.

\section{ABSTRACT}

During the months of november of 1329 to february of the following year, the Chapter of Cuenca often met to try to obtain certain quantity of «maravedís» demanded by the Avignon Curia from the income generated for more than two years in which his headquarters had remained empty after the death of the bishop Pascual, happened in february of 1320 and whose slowness had led them to state of «interdictum » pronounced by the pope John XXII. Those chapter sessions were collected in a "book" which, signed by the canons, and sealed with the stamp of the chapter institution, is kept in the file of the cathedral of Cuenca, being purpose of study from the triple code, paleogeaphic and diplomatic facet, preceded of some short notes which have like aim to fit it in the historical moment which the Church lived and had led the Chapter to the aforementioned canonical situation.

\footnotetext{
* Universidad Autónoma de Madrid.
} 
Los Libros de Actas Capitulares del Archivo de la Catedral de Cuenca han llegado hasta nosotros desde principios del siglo XV, concretamente desde 1413 , lo que parece situarlos entre los de más antigua cronología dentro del mundo archivístico catedralicio, pues son pocos los de otras catedrales que adelantan sus comienzos al siglo Xiv y escasos los que se remontan a la centuria anterior ${ }^{1}$. Desde esa fecha se conservan en Cuenca de forma seriada hasta la actualidad, aunque no podemos pasar por alto las considerables lagunas que se observan en el transcurso de dicho siglo?

Esta referencia a los Libros de Actas se debe a que el documento que ahora publicamos precedido de unas notas codicológicas ${ }^{3}$, paleográficas y diplomáticas, fue considerado como tal en la organización del Archivo Capitular llevada a cabo durante el siglo XVIII y, en consecuencia, encabeza la Sección Secretaría, cuya primera serie es precisamente la de Actas Capitulares ${ }^{4}$, que adelanta así sus inicios archivísticos de forma ficticia casi un siglo, pues en realidad nuestro documento no es un libro de actas, aunque recoja los acuerdos a que llegaron los miembros del cabildo después de varias reuniones tenidas durante los meses de noviembre de 1329 a febrero de 1330 para recaudar entre ellos los 50.000 maravedís en que había sido calculada por el receptor pontificio la deuda de los frutos y rentas que el papa Juan XXII se había reservado para su cámara, durante el tiempo que estuvo la diócesis en sede vacante después de la muerte del obispo don Pascual, ocurrida a primeros de febrero de $1320{ }^{5}$,

Para una panorámica sobre la cronología de los Libros de Actas Capitulares se puede acudir a la Guía de los Archivos y las Bibliotecas de la Iglesia en España, I, Archivos, León 1985.

2 En concreto faltan los años 1423-1433, 1441-1446 y 1467-1484.

3 El profesor Alturo considera oportuno «superar el hábito de no tener en cuenta los aspectos codicológicos de los documentos para compararlos con los de los manuscritos", y a la inversa, opinión que compartimos y que estamos llevando a la práctica en una investigación en la que nos proponemos estudiar el mundo cultural del cabildo conquense en la Baja Edad Media, del que no cabe omitir en absoluto el papel jugado por el scriptorium capitular. J. ALTURO, cMétodos y posibilidades de estudio en historia del libro, con especial atención al códice gótico hispano", en SIGNO. Revista de Historia de la Cultura Escrita, 2(1995) 143-144; también "Charta latinae scriptura libraria exaratae", en Gazette du livre medieval, 29(1996) 60-61.

${ }_{4}$ En la portada lleva doble titulación: una en letra coetánea al texto, y otra en letra del s. XVIII: "Libro sellado de Actas Capitulares. Desde la era 1367, año 1329, noviembre 24». Esta fue la causa de que en una primera organización de los fondos capitulares se colocase encabezando los Libros de Actas, y así tiene la signatura: Archive Capitular de Cuenca (A.C.C.), Secretaría, A. 1.

5 En el Obiturio de la catedral se encuentra la noticia de su fallecimiento ocurrida un 2 de febrero de 1320: "Obiit bone memorie dominus Pascasius conchensis episcopus". A.C.C. Secretaría. Libros, $n^{2} 362$, f. 3 r. Este interesante códice ha sido objeto de algunos estudios parciales por $\mathrm{J}$. TRENCHS ODENA, «EI necrologio-obituario de la catedral de Cuenca: noticias históricas y crónica de la vida ciudadana", Cuenca y su territorio en la Edad Media. Actas del I Simposio Internacional de Historia de Cuenca, 5-9 de septiembre de 1977, Madrid-Barcelona 1982, pp. 341-379; «La cultura jurídico-piadosa del cabildo conquense. (1450-1476)", en Livre et lecture en Espagne et en France sous lancien régime, Colloque de la Casa de Velazquez, París 1981, pp. 35-46. 
«Este es el libro de cómmo se deben pagar las debdas para quitar la eglesia»...

hasta el nombramiento de fray Esteban, que tuvo lugar en agosto de $1322^{6}$.

En realidad a través de nuestro documento se nos descubre todo un contexto de intrincadas deudas recíprocas en el mundo capitular conquense que no es nuestro cometido desentrañar en este momento, no obstante lo cual, creemos oportuno situarlo históricamente a través de unas breves pinceladas.

Como acabamos de referir, en noviembre de 1329 el cabildo decide poner fin a la situación de entredicho en que se encontraba su iglesia por espacio ya de demasiado tiempo, y toma el acuerdo de abonar definitivamente la cantidad que le es demandada por la curia aviñonense, procedente de las rentas generadas durante los casi dos años en que había permanecido vacante la sede conquense; con todo, parece un espacio de tiempo prolongado artificialmente, ya que durante su transcurso el cabildo, haciendo uso legítimo de su derecho, había elegido como obispo a don Pedro Martinez, hasta entonces su deán, al cual rechazó el papa por motivos de política eclesial, pues poco tiempo después se le otorgó la mitra de Évora, mientras que a Cuenca fue enviado el portugués fray Esteban ${ }^{7}$.

No es de extrañar que debido al retraso en la liquidación de la deuda ${ }^{8}$, la curia pontificia no dudase en hacer patente su malestar, no sólo poniendo en entredicho a la catedral, sino rechazando cuantas elecciones episcopales hubo de realizar el cabildo durante este espacio de tiempo, pues a la ya mencionada del deán don Pedro Martínez, puso el veto a las realizadas en los años sucesivos de 1325 y 1326 en la persona del futuro cardenal Albornoz, aún joven miembro del cabildo y perteneciente a una de las familias más influyentes de la ciudadanía conquense. En ambas ocasiones se alegó la juventud del candidato y defecto de órdenes sagradas, carencias que no fueron obstáculo para la designación como obispo

\footnotetext{
6 J. Goñ GaZTAMBIDE, «Juan XXII y la provisión de los obispos españoles», en Archivum Historiae Pontificiae, 4 (1966) 45.

Ibidem, idem. Fray Esteban era obispo de Lisboa y, después de una carrera sostenida por la corona portuguesa, había caido en desgracia ante su rey y buscado refugio en Aviñón, encontrando el papa solución a su situación personal dotándole con el obispado de Cuenca, para lo cual necesitaba la renuncia del elegido por el cabildo, conseguida, presumiblemente, bajo la promesa del obispado de Évora. Puede verse, también, J. DíAZ IBÁNEZ, «El poder episcopal en la diócesis de Cuenca durante la Edad Media", en Espacio, Tiempo y Forma, Serie III, Historia Medieval, 9 (1996) 43, donde al hablar de las elecciones llevadas a cabo por el cabildo dice que la efectuada en la persona de Pedro Martínez fue fallida por renuncia de éste, sin dar ninguna otra explicación.

8 J. GoÑI GaZTAMBIDE, «El fiscalismo pontificio en España en tiempo de Juan XXII», en Anthologica Annua, 14 (1966) 81- 82, 84 y 87, da cuenta de una serie de pagos efectuados por el cabildo conquense a lo largo de estos años.
} 
de Cuenca del también joven y falto de órdenes arcediano de Carvalleda don Juan del Campo ${ }^{9}$.

En este entramado de rechazos y deudas no es difícil advertir el papel preponderante jugado por la familia Albornoz, que sin duda se encontraba entre los gestores de los bienes que la mesa episcopal había recibido durante la sede vacante y que la cámara pontificia reclamaba como suyos. Entre los supuestos usurpadores de tales bienes, sometidos a las censuras canónicas, se encontraría Garci Álvarez, padre del rechazado don Gil, quien en 1324 había prestado al obispo don Esteban la suma de 15. 000 maravedís ${ }^{10}$, aunque las deudas parecen ser recíprocas y no muy claras, pues años después don Gil devuelve 1.000 maravedís que su padre a la hora de su muerte adeudaba a la mesa capitular del cobro de ciertos diezmos ${ }^{11}$.

Sea como fuere, la situación parece haber llegado al límite y durante los meses de noviembre de 1329 a febrero del siguiente año el cabildo puso manos a la obra para satisfacer la antigua deuda con la cámara apostólica y salir así de la situación de entredicho en que se encontraba ya por demasiado tiempo, y aquí tenemos los acuerdos tomados por el capítulo para recaudar los 50.000 maravedís entre aquellos de sus miembros que, a su vez y por diversos motivos, eran deudores con la mesa capitular. Aunque, como ya parecía costumbre, no fueron muy rápidos en llevar a ejecución los acuerdos tomados, pues el importe del expolio y rentas de la vacante que exigía Juan XXII no fue satisfecho hasta tres años

9 G. MOLLAT, Jean XXII (1316-1334). Letres Communes analysées d'aprés les resgistres d'Avignon et du Vatican, Bibliotheque des Écoles françaises d'Athènes et de Rome, $3^{\text {a }}$ serie, 1 bis, fasc. XIII, t. VI, Paris 1910, n²4.882 y $n^{\circ} 29.360$; t. VII, $n^{\circ} 29.895$. Don Juan del Campo murió como obispo de León en 1344, a donde había sido trasladado desde Oviedo en 1332 previa anulación de la elección que los canónigos habían hecho en la persona del arcediano de Valderas Juan Sánchez, quien, no obstante, fue promovido a la sede ovetense, dándose únicamente una permuta de candidatos. J. TRENCHS ODENA, «Aspectos de la fiscalidad pontificia en la diócesis de León (1300-1362)", León medieval. Doce estudios, León 1972, pp.121-122. No podemos olvidar que en estas negativas pontificias, así como en la anterior de don Pedro Martínez, y en los traslados de éste a Évora y de fray Esteban, que lo era de Lisboa, a la sede conquense, como en el caso de León que recoge Trenchs, subyace una patente ingerencia pontificia en los nombramientos y traslados episcopales, que mina cada vez más las prerrogativas de que, con todas las salvedades que queramos, habían disfrutado los cabildos locales. Puede verse a este respecto el breve comentario que hace J. F. CONDE, "Centralismo administrativo y fiscalismo de Aviñón. Sus incidencias en la Iglesia española", Historia de la lglesia en España (Dir. R. García VILLOSLADA), II-2ㄴ. Madrid 1982, pp. 403-404.

10 A.C.C. Institucional, Siglo XIV, no 120 .

11 "El dicho Gil Álvarez, arçidiano, de su propia voluntad, se obligó de pagar para esta dicha paga mille maravedís de recompenssación et emienda de algunos diezmos que falleció de pagar Garçi Álvarez de Albornoz, su padre, del diezmo de Cannamares et del Aldehuela et de otros lugares". (Ap. f. 2v). 
después, cuando en marzo de 1333 se llegue hasta Aviñón el propio don Gil, ahora ya arcediano de Cuenca, para zanjar definitivamente el pleito, conduciendo el importe de la deuda pactada finalmente entre los litigantes en 2.500 florines de oro ${ }^{12}$.

\section{NOTAS CODICOLÓGICAS}

La materia sustentante es un papel de hechura hispano-árabe ${ }^{13}$, de tono marfileño sucio, en cuyas caras se observan brillos dejados por el roce de la piedra satinadora. La pasta, no demasiado batida, está compuesta de fibras de lino finas y bastante largas y sanas, que se distinguen fácilmente en la superficie de la hoja por donde se reparten con regularidad. La textura del papel es más bien delgada ${ }^{14}$, debido a la pérdida de parte de la cola de almidón con que se cubrió, probablemente por haberse mojado en algún momento de su larga andadura, aunque cabe la posibilidad de que simplemente saliera más delgado desde su fabricación. También se observan "caminos» abiertos por insectos en la parte más cercana al doblez de los bifolios ${ }^{15}$.

En el título que lleva en el pergamino que le sirve de guarda ${ }^{16}$ se le denomina como «libro" y así tambien es mencionado alguna otra vez a lo largo del texto y en la suscripción del escribano, aunque creemos que se trata de un término sinónimo de cuaderno ${ }^{17}$, pues no de otra cosa, sino de

12 J. Goñi GazTAmbide, «El fiscalismo pontificio», pp. 67-68. Agradezco a mi buen amigo $\mathrm{M}$. Jiménez el que me haya permitido leer el capítulo de su trabajo "Vere pater pauperum". El culto de san Julián en Cuenca", aún en prensa, donde trata de las relaciones de la familia Albornoz con la curia pontificia de Aviñón.

13 M. C. SISTACH, «El papel árabe en la corona de Aragón», Actas del I/ Congreso Nacional de Historia del papel en España, Cuenca 1997, p. 72, da unas características del papel árabe en todo coincidentes con las de nuestro documento. Aprovecho para dar las gracias a M. C. Sistach por haber analizado unos fregmentos de este papel para poder aportar los datos de su composición y encolado en el presente trabajo.

$14 \mathrm{M}$. Zerdoun BAT-YehOUdA, opina que cuando no se disponen de medios técnicos adecuados es mejor no señalar el grosor de las hojas, aunque, no tratándose en este caso de la realización de ningún inventario, hemos creido oportuno señalar lo que es el resultado de una mera apreciación táctil y visual. "Un protocole de description des papier filigranés», en Gazette du livre medieval, 14 (1989) 22.

15 La presencia de parásitos quizá pudo deberse a lo que apunta J. IRIGOIN, de que el encolado de la pasta con almidón, utilizado en España en lugar de otras colas de origen animal, atrae favorablemente a la carcoma. "L'introduction du papier italien en Espagne», en Papiergeschichte, 10 (1960) 31.

16 Uno en letra coetánea al documento y el otro en letra del s. xvIII, según ya hemos hecho mención en la nota no 4 .

17 Como «libro o quaderno" de apeos es denominado una especie de registro territorial que en 1456 estaba en poder de uno de los regidores conquenses. F. A. CHAcón, La documentación del Archivo Municipal de Cuenca. Estudio diplomático e histórico-institucional, II, Madrid 1995, p. 737 (ed. en microficha). 
cuaderno más que de libro, es la configuración externa del documento que estudiamos ${ }^{18}$. En principio se dispusieron para su elaboración 12 pliegos, que doblados por la mitad conformarían 24 folios, ahora bien, para desarrollar el tenor de la concordia capitular únicamente se necesitaron 14 folios y uno para más escribir dos especies de addendas, cortándose los restantes en un momento posterior, dejando pestaña a la derecha, excepto el último, solidario del primero que está en blanco y sirve de guarda final al cuaderno. Éste se protegió con unas modestas cubiertas de pergamino vacuno rígido, ligeramente tratado y con un acentuado contraste entre el lado piloso, de color amarillento que queda al exterior, y el lado de la carne, de tono lechoso, al interior, en contacto con el papel ${ }^{19}$. Los folios se cosieron al pergamino con hilo de cáñamo de dos grandes puntadas dobles en los extremos unidas por el doblez interior. Para evitar que el papel acabara rasgándose por efecto del hilo bramante, se reforzó el cuaderno colocando a lo largo del pliegue interior una tira estrecha de pergamino, práctica habitual en la confección de los manuscritos en papel ${ }^{20}$ que, a su vez, se cosió al pliego con hilo más fino de color blanco a grandes y sueltas puntadas.

El formato de las hojas, que no parecen haber sido recortadas, pues conservan las barbas, más pronunciadas en los laterales, tiene unas dimensiones de $320 \times 450 \mathrm{~mm}$, que doblado por la mitad da un folio de $320 \times 225 \mathrm{~mm}$. Los corondeles, verticales a la escritura, visibles y no muy tensos, oscilan entre 11 y 12 por cada pliego, con separaciones entre 35 y $45 \mathrm{~mm}$ unos de otros. Una hoja tipo ${ }^{21}$ podría tener la siguiente sucesión de estos hilos: desde el extremo izquierdo al primero $20 \mathrm{~mm}$, y sucesivamente $40,35,42,42,45,40,45,36,42,42$ y hasta el extremo derecho $18 \mathrm{~mm}$. Los puntizones gruesos, pero no excesivamente marcados, se encierran $8 / 10$ por cada $20 \mathrm{~mm}$ y, al igual que señala Valls ${ }^{22}$ en un tipo de papel fabricado en Toledo, se pueden observar a distancias que oscilan

18 L. J. BATAILLON, «Exemplar, pecia, quaternus», en Vocabulaire du livre et de l'écriture au moyen âge, Brépols, Turnhout 1989, pp. 208-210. Véase la definición de cuaderno dada por D. MuzerelLe, Vocabulaire codicologique, Paris 1985, p. 94, 313.01. También P. Ostos-M. L. PARdoE. E. Rodríguez, Vocabulario de Codicología, Madrid 1997, p. 97, 313.01. M. M. CÁRCEL ORTí, (ed.), Vocabulaire international de la Diplomatique, Valencia 1994, pp. 29, 39.

19 Siguiendo la práctica usada en el embutido de los bifolios para la confección de los cuadernos que conformarán los códices. B. Bischoff, Paléographie de 1 'Antiquité romaine et du Moyen Âge occidental, Paris 1985, p. 28.

20 Según han observado en la confección de los manuscritos en papel C. Bozzolo-E. ORNATO, Pour une histoire du livre manuscrit au Moyen Âge. Trois essais de Codicologie quantitative, Paris 1983, p. 113. Véase, también: J. LEMAIRE, Introduction à la Codicologie, Louvain-la-Nueve 1989, pp. $43-44$.

21 Se ha tomado como modelo el primer bifolio.

22 O. Valls I Subirá, La Historia del papel en España, I, siglos X-XIV, Madrid 1978, p. 121. 
entre 15 y $20 \mathrm{~mm}$ otros hilos puntizones más marcados que forman con los corondeles una especie de cuadrícula, aunque ciertamente no muy regular ${ }^{23}$.

El texto se dispone sobre el papel con un mínimo cuidado, la caja de escritura tiene unas dimensiones en torno a los $215 \times 150 \mathrm{~mm}$, con amplios márgenes a los cuatro lados, especialmente generosos los inferiores, en la que se escriben regularmente entre 19 y 22 líneas en cada página; quizá sea esto un aspecto a destacar del esmero puesto por el escribano, ya que no hay apenas otros indicios de excesivo cuidado, pues si bien mantiene con cierta regularidad el inicio de cada renglón en la vertical izquierda, sobrepasa con frecuencia la derecha al no encontrar líneas de justificación, como tampoco hay rastro alguno de restrices. Comete varios errores a lo largo del texto, que soluciona sencillamente tachando o interlineando, según sea la equivocación. Hay unas pocas notas marginales que corresponden a una escritura posterior, quizá ya del del siglo XVI, donde se suelen hacer aclaraciones o repetir una palabra clave del párrafo que señalan ${ }^{24}$.

Por otra parte, ha destacado la inicial «U» de hechura que recuerda la uncial y cuerpo de trazos gruesos enmarcado en una sutil alternancia de guiones y círculos que, aún dentro de la tradición codicológica del gótico, deja de estar totalmente encajada para sobresalir claramente del sangrado de las dos primeras líneas de escritura. Se decora con una sencilla ornamentación de filigranado interior y exterior, todo muy simple, pero que nos muestra la forma de hacer del escribano capitular, que ha querido destacar la letra inicial aplicando cierta originalidad a su trabajo ${ }^{25}$, en el que se ha servido exclusivamente de tinta de color ocre oscuro, la misma empleada para el texto y los signos de parágrafos o calderones en forma de ángulo recto que preceden a todos y cada uno de los «Otrossi» con que se inician los distintos acuerdos tomados por el cabildo.

23 Esta característica del verjurado, además de algunas otras de las descritas, nos conduce hacia Toledo como uno de los posibles centros productores de los que se abastecía el cabildo conquense, hipótesis que ya barajamos al analizar el papel empleado por dicho cabildo para la confección de sus libros de rentas. F. A. CHACón, "Características del papel bajomedieval empleado en el cabildo de la catedral de Cuenca», en IPH-Histoire Internationale du Papier, 8 (1984) 4.

24 Por ejemplo en el f. 2 r, la primera vez que aparece el arcediano Gil Álvarez se dice: «Don Gil de Albornoz fue después Arçobispo de Toledo y cardenal de España". De otro tipo suelen ser las que dicen "Capa», cuando se habla de la capa de seda que tiene la obligación de entregar al cabildo cada nuevo canónigo y que aún algunos no habían satisfecho.

25 De alguna forma está en la línea de las «iniciales ornadas», ya que, si bien carece de colorido, ha recibido un formato y una decoración especial que llama la atención del lector. $H$. TOUBERT, "La lettre ornée», Mise en page et mise en texte du livre manuscrit, Paris 1990, p. 379. 


\section{NOTAS PALEOGRÁFICAS}

La grafía utilizada por el amanuense corresponde a la gótica cursiva corriente, normalmente empleada en Castilla para documentos desde la segunda mitad de la centuria anterior a nuestro documento, y que conocemos tradicionalmente bajo el nombre de "letra de albalaes» ${ }^{26}$. Su morfología es bien conocida de todos los que estudian documentación de esta época, no sólo en cuanto a sus elementos gráficos más típicos del sistema duplicativo de los caídos de $f$ y $s$, sino al conjunto de su abecedario, cuyas características han sido perfectamente descritas en los manuales al uso ${ }^{27}$, lo que nos exime de una detallada descripción de sus letras, así como del sistema abreviativo que de forma más corriente utilizaron los calígrafos que trabajaron con este tipo de letra, del que no es una excepción el escribano capitular conquense.

Nuestro escribano emplea una letra de marcado contraste que no guarda relación entre el cuerpo de la letra y los elementos descendentes que normalmente reduplica en las dos letras más peculiares, empleando indistintamente la doble técnica de trazar el rasgo ascendente hasta la cabeza de la letra sin levantar la pluma, o trazando primero el cuerpo básico y levantar la pluma para volver a la cabeza e iniciar un segundo trazo descendente por la izquierda y paralelo al principal. Del mismo modo, los caídos de otras letras aptas para ello intentan imitar este sistema y, si bien se quedan en el primer movimiento, inician vigorosamente el volteo hacia la izquierda; tal sucede con la $r$ de cruceta y con la $p$. Es muy personal el recuerdo del nexo $c t$, ya que el palo de la $t$ arranca directamente desde la izquierda en curva por encima de la caja sobre la $c y$, a la vez que voltea la pluma, va descendiendo hasta su línea restriz donde se fuga hacia la derecha. Todo ello realizado en una grafía de trazado muy regular y, aun-

26 Recientemente el profesor B. CASADO QUINTANILLA, ha publicado un artículo donde propone una doble línea de trabajo sobre este tipo de letra: por un lado defiende la «propiedad» del nombre de «letra de albalaes" dado por Terreros, teniendo en cuenta que el "albalá" como tipo documental, originariamente comercial y económico, es anterior a que se incorporase habitualmente a la cancillería de Pedro l. Por otra parte observa la influencia en el ductos de sus caídos envolventes hacia la izquierda como proveniente del sistema gráfico árabe, cuya dirección es sinistrógira, teniendo en cuenta, además, que el surgir de esta letra se encuentra en el momento en que se incoporan a la corona castellana las más importantes ciudades musulmanas transmisoras de una rica y apreciada cultura en el mundo cristiano peninsular. "Notas sobre la llamada "letra de albalaes"», en Espacio, Tiempo y Forma; serie III. Historia Medieval, 9 (1996) 327-345.

27 Por ejemplo: A. Floriano Cumbreño, Curso de Paleografía y Paleografía y Diplomática españolas, Oviedo, 1946, pp. 486 y ss. T. MARín (Dir.), Paleografía y Diplomática. Unidades Didácticas. UNED, Madrid, 1978, pp. 331-332, 339-344. A. MILLARES CARLO, Tratado de Paleografía española, Madrid, 1983, I, pp. 193-197, II, figs. 186-194. 
que no se vean «demasiadas concesiones a la estética», la podemos encuadrar a caballo entre las escrituras fracturadas «formata» y la fracturada "de uso común», según la división propuesta por la profesora Sanz basada en la mayor o menor velocidad del ductus con que se han ejecutado ${ }^{28}$.

Como hemos dicho, también el sistema abreviativo usado es el habitualmente utilizado por los escribanos que emplean este tipo de escritura cursiva, pudiendo resaltar que el nuestro lo utiliza a la menor oportunidad, contrayendo y suspendiendo de las palabras las nasales y la vocal $e$, lo que nunca deja de señalar con una rayita horizontal. Del mismo modo se sirve de las letras voladas $i$, e y $o$, cuyo efecto sobre la palabra nos es bien conocido, y de a, que cambia su morfología hasta convertirla en dos líneas paralelas sobrepuestas que, cuando llega el caso, coloca como exponente sobre las iniciales So M para indicar la cotracción de «Suma o de «Garçía», lo mismo que o sobre G para contraer "Gonçalo». Las letras mayúsculas, tanto las principales como las secundarias, son las corrientes que derivan de formas capitales o unciales, con los típicos dobles trazos en su interior que les sirven de sencillos adornos.

Como signos ortográficos sitúa sobre las ies ligeros diacríticos aunque no haya posibilidad de confusión con letras vecinas de parecida morfología, dando la impresión de ser un gesto premeditado de puntuarlas ${ }^{29}$. También el escribano quiere facilitar la lectura empleando un básico sistema de puntuación ${ }^{30}$ compuesto de dos signos, o tres si incluimos a una especie de calderón que en ocasiones hace de punto y aparte en el interior del texto. El signo básico es un sencillo punto sobre el pautado (subdistinctio), usado con profusión en el interior del texto para indicar las diferentes pausas, tanto las breves como las largas, y siempre tres puntos en formación triangular que indefectiblemente cierran párrafo, seguidos de unos rasgueos de pluma entre signos que completan el renglón.

Es mucho más sugerente, por lo que puede suponer de avanzadilla en el mundo gráfico castellano de este momento, la letra del notario capitular que robora y convierte en instrumento público el acuerdo tomado por el ca-

28 M. J. SANZ FUENTES, «Paleografía de la Baja Edad Media castellana», en Anuario de Estudios Medievales, 21 (1991) 532-533.

29 Aunque, según A. Millares CARLo, Tratado, p. 284, el punto sobre la $i$ tuvo su origen en la escritura «itálica», desde donde pasó a la catalanoaragonesa a lo largo del s. xV. No podemos dejar de apuntar aquí la opinión de E. CASAMASSIMA, Tradizione corsiva e tradizione libraria nella sacrittura latina del Medioevo, Roma, 1988, pp. 116-119 y 164, a este respecto, como un elemento propio de la «Lettera moderna".

30 J. VEZIN, «La ponctuation aux $x_{11}{ }^{e}, x^{e}$ et $X^{e}$ siècles», Mise en page et mise en texte du livre manuscrit, Paris 1990, p. 443. 
bildo conquense y que además escribe dos addendas a dicho acuerdo en abril de 1330 (f. 15 r), y de las que nos ocuparemos en su momento oportuno. En la letra de Pedro Martínez, que así se nos identifica el notario, se vislumbran ya algunos rasgos típicos de las escrituras bastardas, pues los caídos de letras como $f, p, q$ y $s$, gruesos al principio, se van ahuesando hasta convertirse en agudos al final mientras ocupan los espacios interlineales, y también los de otras letras que descienden, pero sin descolgarse tanto, como la mayaría de las ies o la $r$ recta de iniciación bífida que aún no se ha abierto; todo lo cual patentiza el claroscuro vertical. La $s$ al final de dicción, morfológicamente sigmática, se alarga ligeramente por debajo de la línea de renglón aunque aún no ha llegado a tomar la forma de $B$ que será típica de la bastarda.

Encontramos otras características gráficas en los textos mencionados, como por ejemplo la letra $g$, acaso una de las más radicalmente distinta a sus homónimas del documento principal, hecha con tres golpes de pluma: la cabeza es casi un semicírculo que se cierra mediante una lineta con la que se une a la letra siguiente, mientras que la parte inferior, totalmente bajo el pautado, se ejecuta de un solo movimiento, iniciado vertical para inmediatamente desarrollar una elipse cerrada de canon grande, nada proporcionado a la cabeza. También son dignos de mención los astiles de letras como / y $b$ que en muchos casos forman un cayado panzudo y prolongado hasta poder tangenciar con el astil sobre la línea del renglón. En todas las palabras iniciadas por «con» sustituye esta sílaba por el antiguo signo carolino, realizado de un solo y ágil golpe de pluma descendente hacia la izquierda que una vez ocupado el espacio interlineal asciende a la derecha describiendo un amplio bucle. Idéntico ductus encontramos en el segundo trazo de la $h$, pues si desciende ligeramente inclinado hacia la izquierda voltea la pluma y cambia bruscamente de dirección para ascender por la derecha describiendo el consabido bucle, y lo mismo sucede frecuentemente en algunos trazos finales de $n$, en los que el escribano ejecuta un rápido movimiento en rasgueo de la pluma, todo lo cual nos recuerda a la minúscula cancilleresca italiana ${ }^{31}$. Sin embargo, en algunas palabras que empiezan por $f$ desarrolla esta consonante como una especie de híbrido, ya que el primer trazo coincide con la hechura bastarda, mientras que el segundo, arrancando de nuevo desde la cabeza de aquél, desciende para reduplicar el trazado por la izquierda, en la más clara tradición de albalaes, y algo semejante hace en las pocas ocasiones en que ha de utilizar $j$ al inicio de dicción. En realidad, aún dentro de la aparente pesa-

\footnotetext{
31 A. Petruccl, Breve storia della scrittura latina, Roma 1989, pp. 151-154.
} 
dez gráfica, indica un dominio notable del oficio por parte del escribano, que señala diestramente los trazos gruesos y finos debido a su experiencia en el manejo de la pluma cortada a bisel, dando como resultado una escritura que nos ha recordado la síntesis gráfica de que habla Gimeno Blay, aunque en este caso no sea debido tanto a las astas en «banderole», que ciertamente aún no lo son, sino a los grandes bucles descendentes dextrógiros, que también se encuentran en la documentación producida por la cancillería aragonesa a principios del siglo XIV ${ }^{32}$.

Sin pretender ahondar demasiado en esta hipótesis, únicamente dejamos constancia de lo que nos parece una precoz presencia en el scriptorium del cabildo conquense de un tipo de letra que apunta hacia el ductus bastardo, y hasta lo que conocemos también en todo el ámbito castellano, pues lo más extendido es que debió penetrar en España traída por los funcionarios franceses que vinieron con sus reyes a gobernar Navarra ${ }^{33} \mathrm{O}$, como opina L. D'Arienzo, favorecidas las vías de penetración gráfica en la corona de Aragón por una mayor y más constante presencia de literatura francesa gracias a los matrimonios de Juan I con sucesivas princesas del país vecino ${ }^{34}$. No obstante, el profesor Gimeno Blay, en el estudio sobre La escritura gótica en el país valenciano después de la conquista del siglo $X I I I^{35}$, cuando habla sobre los problemas de la periodización de esta letra y después de haber analizado una serie de colecciones documentales, llega a la conclusión de que en la Península se pueden encontrar documentos en letra bastarda, de forma seriada, desde el segundo cuarto del siglo XIV, también, eso sí, de origen extra peninsular y de la mano de los mismos profesionales de la escritura, aunque en muchos casos pueden ser naturales educados en universides de fuera de nuestras fronteras, sin olvidar la ascendencia que ejercía sobre el colectivo de estudiantes clérigos la cultura de la sede papal aviñonesa ${ }^{36}$.

32 F. M. GIMENo BLAY, «A propósito del manuscrio vulgar del trescientos: el escurialense K.I.6 y la minúscula cursiva libraria de la Corona de Aragón, en Scrittura e civiltà, XV (1991) 206, 216.

33 A. Millares Carlo, Tratado, pp. 112-113.

34 L. D'ARIENZO, «Alcune considerazioni sul passagio della scritura gotica all'umanistica nella produzione documentaria catalana dei secoli XV e XV», en Studi di Paleografia e Diplomatica, Padova 1974, p. 203.

35 Valencia 1985, pp. 105-111.

${ }_{36}$ Omitimos citar los trabajos de A. M. ARAGó y de F. C. CAsula, respecto a este tema porque sus opiniones han sido recogidas en la obra citada en la nota anterior del profesor GIMENO BLAY, pp. 107-109. Es muy interesante el posterior artículo del mismo profesor donde matiza algunas de sus opiniones sobre los tiempos y tipos gráficos utilizados en la corona de Aragón, «A propósito del manuscrito", sobre todo pp. 214 y ss. Ya en un anterior artículo en colaboración con el profesor J. TRENCHS ODENA, "La escritura medieval de la corona de Aragón», en Anuario de Estudios Medievales, 21 (1991) 505-506, habian hablado de unas tendencias gráficas que desde la prime- 
Pedro Martinez, sochantre y notario capitular, ha dado fe pública al documento, recogiendo la iussio del cabildo conquense, y es el autor material de los textos vertidos en una grafía que es ya preludio a muchas de las singularidades que le son propias a la littera bastarda,como acabamos de señalar; por eso creemos que nuestro escribano ha entrado en contacto con instrumentos escritos en ese tipo de letra que según Cencetti ${ }^{37}$ tiene su origen a finales del siglo XIII en Francia, presumiblemente por haber sido educado en alguna universidad francesa o probablemente italiana, lo que no era nada raro en la formación de los clérigos, tal como ya había dicho el profesor Aguadé ${ }^{38}$ al hablar de los centros universitarios que ejercían una mayor atracción sobre los miembros del cabildo conquenses, entre los que, lógicamente, se encontraban los más importantes del momento, como Bolonia, Roma, París y, desde principios del siglo XIV, la propia Aviñón gracias a la política universitaria iniciada por Clemente $\mathrm{V}$, quien al parecer concedió a los miembros de nuestro cabildo la gracia de no interrumpir el disfrute de sus beneficios mientras se encontrasen realizando estudios en alguna universidad.

A este respecto, hojeando el primer libro de rentas ${ }^{39}$, el único que podemos considerar coetáneo del documento que nos ocupa, pues abarca los años de 1336 a 1339 , hemos encontrado algunos asientos que dejan constancia de lo normal que era en la vida del cabildo conquense contar con que algunos de sus miembros se encontrasen ausentes o solicitasen licencia de sus obligaciones capitulares por motivo de sus estudios.Así se reflejan algunas partidas de maravedís para unos cuantos canónigos que han estado fuera estudiando (f. $15 \mathrm{r}$-v), o se paga a Gonzalo Martínez lo correspondiente a su ración de los cinco meses que ha estado ampliando estudios (f. 17); también se reconoce el permiso de cinco años que disfru-

ra mitad del s. XIV están preludiando las formas características de la "minúscula cancilleresca y bastarda», que serán las dominantes en la segunda mitad del siglo, prestando especial atención a la influencia que sobre elias pudo ejercer la minúscula cancilleresca italiana a partir de la conquista de Sicilia en 1283, y los instrumentos gráficos procedentes de la curia aviñonesa de principios del s. XIV. Puede verse también el comentario que sobre «la cuestión de la bastarda» hace M. C. ÁlVAREZ MÁRQUEZ, «Escritura latina en la plena y baja edad media: la llamada "gótica libraria" en España», en Historia. Instituciones. Documentos, 12 (1985) 407-410, lams. XVII-XX. También el profesor S. AGUADÉ, en un estudio sobre la formación del clero conquense, habla del enorme atractivo que para el clero castellano en general ejercía la sede de Aviñón, La formación intelectual del clero conquense a fines de la Edad Media, Madrid 1981, p. 23.

37 G. CENCETTI, Lineamenti di storia della scritura latina, Bologna 1997, pp. 208-211, donde habla de las características de la letra bastarda.

38 "La formación intelectual», pp. 18-19; de forma más general, puede verse del mismo autor, "Las universidades y la formación intelectual del clero castellano en la Edad media", Universidad, cultura y sociedad en la Edad media, Alcalá de Henares 1994, pp. 159-206.

39 A.C.C. Mesa Capitular, R. 543. 
ta Ramón Bernal a la hora de retribuirle los frutos de su beneficio, aunque no se indica la universidad donde está (s/f), o se toma nota del día que empieza sus estudios en Aviñón el canónigo Juan de Luna, según certificación presentada por el maestro en teología, o se concede licencia de siete años a Gonzalo Fernández, racionero, para ir a Bolonia (s/f), todo sin que se observe nada que nos induzca a pensar que esto no sea algo habitual en el normal funcionamiento del cabildo.

No podemos terminar estas notas paleográficas sin hacer una breve referencia a las firmas de los capitulares que validan el acuerdo tomado colegialmente y a las de aquellos otros canónigos, prácticamente los mismos, que testimonian la segunda de las addendas a que nos hemos referido anteriormente. Dichas firmas autógrafas son un elemento inmejorable para mostrarnos el grado de cultura gráfica alcanzado por el colectivo de élite de los clérigos conquenses en la primera mitad del siglo XIV y de cada uno de ellos en particular ${ }^{40}$, dejando a un lado, por no ser de nuestra competencia, los aspectos psicológicos que de sus autores nos pudieran revelar ${ }^{41}$.

Hace ya dos décadas el profesor A. Petrucci 42 estableció tres grados de conocimiento gráfico a través de la observación de las escrituras personales: elemental de base, usual y puro, añadiendo posteriormente un cuarto grado propio de los "profesionales de la escritura" ${ }^{43}$. Si nosotros quisiéramos enmarcar la educación gráfica de esta élite clerical en alguno de los grados mencionados, tendríamos que concluir que, quizá con algunos matices, todos ellos se inscriben en el campo de las escrituras de ductus gótico cursivo, usual en el momento en que se redactó el texto, en

40 Es abundante la bibliografía que a este respecto se ha publicado, sirvan como ejemplo: A. Petruccl, «Prospetive di recerca e problemi di metodo. Per una storia qualitativa del alfabetismo", en Sulle vie della scritura, Salerno, 1989, pp. 21-37; y dos trabajos sumamente sugerentes publicados en el $n^{\circ} 21$ del Anuario de Estudios Medievales (1991), uno del mismo profesor A. PETRUCCl, «Storia della scrittura e storia della società», pp. 307-322, sobre todo para lo que ahora nos interesa a partir de la p. 317; el otro de A. BARTOLI LANGELI, "Storia dell'alfabetismo e metodo quantitativo", pp. 347-367.

41 A este respecto pueden verse los acertados comentarios del desaparecido profesor $\mathrm{T}$. Marín, “Grafología y Paleografía», I Congreso Español de Grafología, Madrid 1981, pp. 359-373.

42 «Scrittura, alfabetismo ed educazione gráfica nella Roma del primo Cinquecento», en Scrittura e civiltà, 2(1978) 167-188. Una aplicación de esta triple capacidad gráfica en un campo más amplio que el de las simples firmas, como es la observación de la escritura utilizada para la confección de “albaranes» en la segunda mitad del siglo xv, puede verse en M. L. MANDINGORRA, "Usos privados de la escritura en la Baja Edad Media. Secuencias espacio-temporales y contexto de uso", en Las diferentes historias de letrados y analfabetos, Universidad de Alcala de Henares, 1994, pp. 77-80.

43. «Storia della scritura», p. $\mathbf{3 1 7}$ 
consonancia con el colectivo alfabetizado al que pertenecen, que precisa de la escritura no como un medio de vida sino como algo necesario en su propio status social y cultural.

Nos parece que la comunidad canónica tiene una más que media cultura gráfica, pues todos escriben sus nombres ejecutando los trazos con fluidez y agilidad en un módulo medio, con nexos y sabiendo utilizar el sistema y los signos abreviativos existentes a su disposición, sobre todo aquellos que emplean el latín para escribir sus nombres y la categoría o cargo desempeñado. Así emplean el signo de semicolon, asentado sobre el renglón, para el sonido final us, entre otros "Matheus Petri, canonicus», quien a su vez coloca $i$ sobre $t$ para elidir $r$ en «Petri», lo que también hace «Johanes Petri, archipresbiter», quien además utiliza la línea horizontal para suprimir la nasal del nombre, la vírgula exponencial sobre $p$ con sonido re y un bucle nexado al trazo horizontal de $t$ que baila estas letras en «archipresbiter». Es normal el empleo de las siglas en la onomástica, como $G$ con a de lineta sobrepuesta para «Garçia», la contracción $M z$ sobrevolada de una especie de a abierta por la base y con el trazo derecho prolongado para "Martínez", y hacer uso del caído de $p$ partido para formar «Pero» y «Pérez». El alfabeto mayúsculo que conocen es el propio de la gótica cursiva del momento.

Si quisiéramos destacar una firma del conjunto capitular, tendría que ser la de un canónigo de nombre extraño al santoral castellano ${ }^{44}$ y cuya grafía nos parece más evolucionada que la del resto de sus colegas, siendo patente el dominio que tiene de la pluma en el juego de claroscuros y rompimiento de las curvas de $n, m, u$, y $s$ final sigmática con doble panza a la derecha; lástima que para escribir su nombre no precise de letras con astiles descendentes y nos prive de ver su más que posible ahuesamiento. Debido a la singularidad de su nombre no utiliza abreviatura, salvo el signo especial para el sonido «con» al principio de "concedo», de morfología semejante al empleado por el escribano suscriptor, y débiles diacríticos sobre las dos ies que encierra su nombre, según una práctica común cuando esta letra se encuentra entre otras de fisonomía semejante con las que se puede confundir, como sucede en el caso que nos ocupa. $\operatorname{Sin}$ embargo, en el ya mencionado Libro de Rentas, que se nos ha descubierto como un verdadero filón gráfico por las variadas manos que intervienen en su confección, pero sobre todo por la gran cantidad de personas que firman los asientos, incluso poniendo breves frases, hemos encontrado a

44 Además emplea una fórmula diferente al resto de sus colegas en la validación de la concordia capitular: "Ego Caçanimicus, concedo hoc". 
nuestro canónigo firmando con su apellido, "Caçanimico Royz» ${ }^{45}$, y en otro lugar escribiendo algunas palabras de accesión al apunte, como «Caçanimico lo otorgo» ${ }^{46}$. En éstas le hemos visto emplear una len «banderola», propia de la minúscula cancilleresca italiana ${ }^{47}$ que, por otra parte, no es el único miembro del cabildo que la utiliza ${ }^{48}$, y una $r$ de martillo asentada en la línea, pero tan abierta que bien pudiera pasar por una $v$, a la vez que una $y$ con un trazo descendente en bucle semejante a los ya descritos, todo lo cual nos sugiere una vez más la simbiosis gráfica anteriormente mencionada. Por ultimo, y teniendo en cuenta el destacado papel que está llamado a jugar en un futuro no lejano, mencionamos la firma del que será cardenal y gran estadista y legislador, ahora aún joven arcediano de Cuenca, don Gil Álvarez de Albornoz ${ }^{49}$, de quien encontramos dos firmas realizadas con una letra muy rápida y personal, en nada ateniéndose a academicismos como claramente lo hacen algunos otros miembros del cabildo.

\section{NOTAS DIPLOMÁTICAS}

Desde el punto de vista jurídico-diplomático, nuestro documento no es otra cosa que el acta de la concordia establecida a lo largo de varias sesiones capitulares sobre el único y mismo tema de reunir entre los propios componentes del cabildo la cantidad de dinero que necesitan para salir definitivamente del entredicho pontificio que pesa sobre la catedral, y que, debido a la complejidad que el tratamiento de todo asunto económico lleva consigo, han necesitado algo más de dos meses para llegar a la solución que consideran satisfactoria para todos.

\footnotetext{
45 A.C.C. Mesa Capitular, R. 543 , f. 42 r.

46 Ibidem, f. $5 \mathrm{r}$.

47 A. Petrucci, Breve storia, p. 152.

48 Entre otras firmas, la que se muestra con una más clara educación gráfica según modelos italianos es la de "Guillem Vitalis, scolasticus", quien escribe en una perfecta escritura minúscula cancilleresca, según la describe Petrucci, con amplias "anse triangolari in alto" de la $l$, y el "raddoppiamento delle aste di " $f$ " ed "s" $"$. Ibidem, pp. 152-153. Sería muy interesante, y en absoluto lo descartamos para un futuro no lejano, realizar un minucioso estudio paleográfico sobre las manos base que intervienen en la confección de estos libros de contabilidad, a las que se añaden una variada gama de notas autógrafas y firmas que componen un verdadero muestrario de escrituras personales que quizá nos haría replantear algunas de nuestras apreciaciones relativas a cronologías y vías de influencia en el mundo gráfico castellano.

49 Don Gil recibió su primera educación junto al arzobispo de Zaragoza, Jimeno de Luna, hermano de su madre, que posteriormente amplió en Francia hasta conseguir el grado de doctor en Decretos. Para una aproximación al personaje, puede consultarse: J. BENEYTO, El cardenal Albornoz. Hombre de Iglesia y de Estado en Castilla y en Italia, Madrid 1986.
} 
Según parece, ha sido sacada de un original que, como testimonio escrito ${ }^{50}$ de lo acordado en dichas sesiones, había mandado elaborar el cabildo, quizá para entregarlo al camarero pontificio como prueba de su buena disposición para restablecer su situación canónica, lo que convierte a nuestro documento en una copia «concertada» ${ }^{51}$, según palabras de la propia suscripción notarial, a la que se ha dotado de todas las garantías legales que precisa.

Su estructura diplomática guarda cierta semejanza con la vista en las sesiones recogidas en las actas del municipio ${ }^{52}$, lógico al tratarse de dos instituciones paralelas aunque sus acciones se ejerzan en campos distintos de la vida ciudadana. Como no hay invocación ni rastro de signo de cruz, se abre el protocolo, según es preceptivo en los documentos tipo acta, por la data, que en este caso, careciendo de la tópica explícita, se compone de todos los elementos crónicos desarrollados literalmente: día de la semana y del mes, citado por su nombre, seguido del año según la era hispana. Sin solución de continuidad se citan las personas que toman parte en la reunión y se indica el motivo concreto que las ha convocado, según un orden establecido:

- Presentación de la persona jurídica, "llegado el cabilldo de la eglesia de Cuenca", lo que vendría a ser una intitulación institucional.

- Especificación del motivo de la reunión, previo haber dejado claro que no lo hacen por iniciativa particular sino convocados, según la costumbre, "a son de la campana mayor».

- Cita nominal de los canónigos asistentes a la sesión. Se indica nombre, apellido y cargo u oficio, según un orden jerárquico que los distribuye en dos columnas, referentes del lugar litúrgico ocupado en el coro en razón de la categoría del cargo desempeñado y la antigüedad de acceso al cabildo, lo que sería una intitulación formal.

Después de hacer una breve recapitulación del asunto que los reúne, se da paso a la actio, dejando claro que surge de forma colegiada, por unanimidad y sin desavenencias, "acordaron todos de una voluntad", que pondrá en marcha el proyecto pergeñado para recaudar la cantidad que precisan, y que se concretará en tres apartados, según la procedencia del dinero que se proponen recaudar:

\footnotetext{
A. Floriano Cumbreño, Curso general, pp. 225-226.

51 F. PINO REBOLLEDO denomina como «concertaciones» a un tipo de copias actuadas por el escribano municipal quien indica en la suscripción su carácter con la palabra «conçertose», en paralelo a lo que observamos en la suscripción del notario capitular. Tipología de los documentos municipales (siglos XII-XVII), Valladolid 1991, pp. 241-242.

52 F. A. CHACÓN, La documentación, II, pp. 645-658.
} 
«Este es el libro de cómmo se deben pagar las debdas para quitar la eglesia»...

En el primero se reflejan los deudores entre los pertenecientes a la propia institución, detallando el motivo de la deuda. La relación se inicia por "Primeramente fallaron" y se continúa por "Otrossí fallaron", precedidos del correspondiente calderón. Esta primera parte concluye con una nueva referencia dispositiva "ordenaron et acordaron", reforzada con cláusula de obligación, "obligose a ello por cabilldo", de hacer efectivas las deudas correspondientes en un plazo determinado, de todo lo cual dan traslado al obispo mediante una carta que insertan precedida de la consabida frase "fecha en esta guisa». Después de su inserción se pone una cláusula de juramento, obligándose el cabildo a "no revocar» lo contenido en ella.

Dicha carta es calificada en su anuncio de validación como «carta abierta" ${ }^{53}$, aunque su estructura tiene mayor afinidad con las que diplomáticamente conocemos con la denominación común de «misivas». Se inicia con un protocolo donde se expresa directamente su destinatario con una fórmula de cortesía que es muestra de respeto y deferencia hacia un superior, «Al mucho onrrado padre et sennor don Oddo, por la graçia de Dios obispo de Cuenca", le sigue inmediatamente una intitulación conjunta de los capitulares iniciada por el pronombre "Nos" e indicación de sus nombres y cargos según el orden jerárquico acostumbrado, para terminar con una fórmula de sumisión y respeto hacia su interlocutor, «besamos vuestras manos y nos encomendamos en vuestra graçia".

Con esto nos introducimos en el texto mediante un expositivo que narra los hechos que han movido al cabildo a tomar una serie de acuerdos $y$ asumir los compromisos pertinentes para salir del entredicho papal, comunicándoselo así a su obispo. Concluye esta parte con una cláusula que anuncia la validación de que consta e indicación de la categoría diplomática concedida por el scriptorium capitular, «Et desto vos enviamos esta nuestra carta abierta e seellada con nuestros seellos e so scripta de nuestros nombres». A esto se añade la manifestación expresa de un miembro del cabildo que estaba ausente corroborando todo lo actuado por sus co-

53 Esta denominación nos sugiere el documento emitido por la cancillería real castellana, redactado sobre pergamino y autenticado con el sello de cera pendiente; sin embargo el emitido por el cabildo conquense en nada se parece a sus homónimos reales. No obstante con esta denominación se encuentran cartas otorgadas por concejos castellanos y analizadas por $F$. PINO REBOLLEDO, Tipología de los documentos municipales (siglos XII-XVII), Valladolid 1991, pp. 53-60, con las que nuestra carta tiene una verdadera línea común en su desarrollo interno. Puede verse también una carta emitida por el concejo de Albarracín que recibe igual denominación en la cláusula donde se anuncian los medios puestos para su validación, publicada en F. A. CHAcón, «Relaciones de vecindad entre Albarracín y Cuenca. Una aportación a la Diplomática municipal aragonesa", en Anales de la Universidad de Alicante. Historia Medieval, 10 (1994-1995) 307-308, ap. $n^{\circ} 5$. 
legas. Las fórmulas que cierran el tenor se reducen a situar la carta en el espacio y en el tiempo. La data tiene como incipit, «Dada», seguido del elemento tópico, en este caso el espacio concreto donde tienen lugar las reuniones capitulares, "en el cabilldo de la eglesia de Cuenca", o sala capitular situada en el claustro mandada construir por el obispo Diego Martínez en la década de los setenta del pasado siglo ${ }^{54}$, más los elementos crónicos que aportan el día del mes y el cómputo anual según la era hispana, todo literalmente expresado.

La segunda vía para recaudar el dinero que precisa, la encuentra el cabildo urgiendo el importe de la «capa de seda de preçio de cada quatroçientos maravedís», que establecía la constitución promulgada en 1324 por el obispo fray Esteban ${ }^{55}$ como preceptivo para cada nuevo canónigo que se incorporaba a la institución capitular, lo que, por otra parte, no parece que fuese muy tenido en cuenta a la vista de los morosos que se relacionan en nuestro documento. Se inicia, igualmente, haciendo referencia al acuerdo capitular tomado a este respecto, con los verbos dispositivos «ordenaron et mandaron» y desarrollado con idéntico esquema de «Primeramente», continuando con «Otrossí fallaron», precedidos del consabido calderón.

El tercer bloque se refiere a deudores en general por distintos conceptos, y se expresa de forma parecida a los anteriores, aunque podemos encontrar incipit como "Otrossí ordenaron et mandaron», u «Otrossí pidieron por merçed», según quién sea el receptor del acuerdo.

Una vez determinados los deudores, lo cual se ha llevado a cabo en sucesivas reuniones capitulares mantenidas, es llegado el momento de pasar a ejecutar lo acordado, para lo cual se precisa la ratificación del cabildo convocado a tal fin, que no será del modo acostumbrado « a son de la campana mayor», sino personalmente por el portero, acompañado del notario capitular, portador de una citación formal ante diem, de la que se explicitan sus elementos validaticios, "seellado e so scripto del seello e del nombre del deán, Ferrand Garçía, antel dicho notario e testigos", insertándose con el siguiente y sencillo esquema:

54 G. PALOMO, La catedral de Cuenca en el contexto de las grandes canterías catedralicias castellanas en la Baja Edad Media, I, pp. 199-200. Tesis doctoral leída en la Universidad Autónoma de Madrid el 23 de noviembre de 1995, inédita.

55 "Divino cultui quem desideramos augeri salubriter providere volentes, statuimus ut quicunque canonicos mansionarius noviter in ecclesiam nostra vigore apostolice seu cuiusuis alterius auctum effectus pluniale (sic) seu capam de serico cum debitis aurifrisicis et argenteis decentibus ornamentum valoris quadrigentorum morabetinorum usualium ad minus». A.C.C. Secretaría. Libros, $n^{\circ} 363$, f. 1 r. 
- Data: literal únicamente crónica. iglesia

- Expositivo: mención a la situación canónica en que se encuentra la

- Dispositivo: de inicio en cierto modo promulgativo que incluye una dirección general y la convocatoria formal.

Después de nominarse a los capitulares que han sido avisados personalmente se da paso a la sesión capitular, cuyo protocolo se estructura de forma idéntica al de aquel que abría el documento, señalando únicamente ahora en la data la mención del día último del mes como "postrimero», según se acostumbra en la Diplomática hispana. Asisten todos los canónigos convocados, excepto aquellos de los que ya se había informado su ausencia y los arcedianos, quizá por encontrarse en el pueblo cabeza de su jurisdicción y no poder desplazarse con la premura que se les requiere. Se da paso después a un expositivo donde se presenta por escrito, para aprobación de los asistentes, todo lo tratado hasta el momento, tomando el acuerdo unánime de cumplirlo, aunque introducen la enmienda de prolongar el tiempo fijado en anteriores sesiones para hacer efectivas las correspondientes deudas, seguido de una cláusula de compromiso que encierra las garantías de guardar y cumplir lo acordado bajo juramento ante los evangelios y en presencia del notario capitular.

La signación de los asistentes y el posterior sellado, que cerrará legalmente el documento concordado por los miembros del cabildo, se anuncia mediante una cláusula iniciada con la expresión «Et por mayor firmeza», que de alguna forma está en la línea de hacer irrebatibles los negocios que clausura ${ }^{56}$, respaldando lo actuado con el compromiso de la institución capitular, además de con las firmas de sus miembros, con la aposición del sello que la simboliza, tratándose más de una cuestión legal interna del propio cabildo que de sus repercusiones públicas, lo que se obtendrá recurriendo a la intervención notarial. También hay una manifestación expresa de la importancia concedida al documento cuando se manda su custodia en el tesoro, junto al resto de objetos preciosos que conserva la comunidad catedralicia ${ }^{57}$.

56 Véase el sentido de esta cláusula en J. BonO, «La práctica notarial del reino de Castilla en el siglo XIII. Continuidad e innovación», en Notariado público y documento privado: de los orígenes al siglo XIV. Actas del VII Congreso Internacional de Diplomática, Valencia, 1986, I, Valencia 1989, p. 505 .

57 Es esta una práctica antigua y comunmente extendiada, que da idea de la importancia que se concedía a los documentos. O. GUYOTJEANNIN, «Le vocabulaire de la Diplomatique en latin mediaval", en Vocabulaire du livre et de l'écriture au moyen âge, Turnhout-Belgique t989, pp. 130 y ss. 
La data, en este caso de la conscriptio del «libro» y demás formalidades legales, así como del testimonio de su ubicación definitiva en el tesoro, cumpliendo así lo dispuesto anteriormente, se expresa, según viene siendo habitual, por la era hispana, y el día y mes por el sistema moderno, careciendo, igual que las anteriores, de topónimo explícito.

Como se ha dicho anteriormente, las firmas de once canónigos, acompañadas de sus respectivas rúbricas, clausuran la concordia capitular, y como signo externo de validación aparece, efectivamente, el sello de cera del cabildo conquense, pendiente de un hilo bramante. La técnica empleada en su aposición ha consistido en taladrar por dos veces, fuera de las puntadas de costura, el doblez de los bifolios para pasar un doble, triple en el interior, hilo bramante formando una gran lazada. El sello es de color oscuro y doble ojiva con ligeros rebordes donde duermen restos de la capa de color rojizo sobre la que se grabó la única impronta, ya que el reverso es en naveta. Su estado de conservación es muy malo y sólo se mantienen unidas al cordón las dos ojivas, observándose en la inferior un pequeño cuenco, símbolo parlante de la ciudad ${ }^{58}$, que aparece como escabel a los pies de la Virgen en otros sellos capitulares que se conservan intactos ${ }^{59}$.

La suscripción notarial ${ }^{60}$, que en este caso no pasa de ser un mero requisito para corroborar el carácter público del negocio jurídico escritu-

58 Véase e este respecto, A. CHAcón, "Sellos reales y del concejo en el archivo municipal», en Ciudad de Cuenca, 89 (1987) 54-58.

59 En un documento del año 1312 (A.C.C. Instiucional, $n^{\circ} 247$ ), el cabildo utilizó un sello de las mismas características, pero colocando sobre la impronta un fino papel, del que no se ha conservado ni rastro en el que tratamos, en el caso de que lo tuviera. Las dimensiones son $65 \times 40 \mathrm{~mm}$, y representa a la Virgen sentada en silla curul de brazos semejantes a cabezas de leones y pies que figuran garras, apoya sus pies en sendos escabeles sostenidos por un cuenco. En la cabeza se ciñe una corona de tres florones sobre un velo que cae por encima de sus hombros; el vestido es una amplia túnica de plieges elegantes y anchas mangas asomando por la derecha la mano que sujeta un cetro flordelisado. El Niño descansa sobre la rodilla izquierda de la Madre y aparece desnudo, sujetando con su mano izquierda lo que puede ser una manzana y la derecha levantada para bendecir, sobre su cabeza aparece el nimbo. Este sello introduce algunas modificaciones en la representación con respecto a los tres modelos que sucesivamente ha utilizado el cabildo a lo largo del siglo XIII, aunque ha conservado la misma leyenda y grafía que empleaba a finales de dicho siglo. Bordea el campo, entre gráfilas de puntos, una leyenda en capitales y unciales, con la $n$ minúscula de ductus gótico, y se emplean unos puntitos exponenciados para abreviar una $M$ final y una $n$ en situación intermedia: «S. CAPITVLI CanOnICORV[M] CO[n]ChEnSIVM». Puede verse, una referencia a los sellos empleados por el cabildo conquense en A. CHACÓN, "Sellos episcopales y del cabildo en el archivo capitular de cuenca. 1182-1300", en Revista UNED, 3 (Cuenca, 1988-89) 135-136.

60 Se denomina como «notario» en sintonía con la tradición de la lglesia que gustaba designar así a sus fedatarios. Véase, J. BONO HUERTA, Historia del Derecho notarial español, l.1, Madrid 1979, pp. 112-113. J. MARTiNEZ GIJón, «Estudios sobre el oficio de escribano en Castilla durante la Edad Moderna", en Centenario de la ley del notariado, Madrid 1964, I, pp. 280-281. 
rado ${ }^{61}$, según hace constar el propio notario en la iussio recibida del cabildo, la pone, como ya sabemos, "Pero Martínez", quien ejerce la fe «publica» por autoridad del obispo y del propio cabildo ${ }^{62}$. Deja constancia de su presencia durante las negociaciones documentadas junto a los miembros del cabildo, y certifica el absoluto paralelismo entre la copia y el original, a la vez que para salvarla de posibles fraudes da las características materiales del soporte empleado, así como el número de las hojas que han sido necesarias para escriturarla ${ }^{63}$, además de aludir a otras formalidades externas que ha puesto para salvaguardar su autenticidad ${ }^{64}$. A todo ello da utilidad pública, como receptor de la iussio capitular, cerrándolo con la aposición de su signo, previa una referencia a la data de la conscriptio documental.

Por último, en el f. $15 \mathrm{r}$, el mismo notario escribe dos addendas a la concordia que de alguna manera la completan.

La primera es la constancia de haber hecho entrega de una cantidad de maravedís a los receptores nombrados por el cabildo como responsables del dinero reunido. La segunda nos presenta una fórmula común de arriendo de las deudas capitulares, en este caso las que se han descrito a lo largo del documento, que evita al cabildo toda una serie de gastos de burocracia y le permite tener liquidez inmediata para hacer frente a sus obligaciones con la cámara apostólica. De estas deudas se hace solidario

61 Es interesante a este respecto la opinión de A. RIESCO, «Consideraciones en torno a la tipología documental y validación notarial de una carta de hermandad suscrita por el concejo de Úbeda y la Orden de Calatrava», en Notariado público y documento privado: de los origenes al siglo xIV. Actas del VII Congreso Internacional de Diplomática, Valencia,1986, Valencia, 1989, pp. 561-575.

62 La actuación y jurisdiccion de los «notarios» nominados por la autoridad eclesiástica, en ocasiones conjuntamente por el obispo y cabildo, como es el caso presente, para escriturar documentos es ya de todos conocida, puede verse, no obstante, la clásica obra de J. Bono, Historia del Derecho, 1.1, pp. 112-114, I.2, pp. 193-197; y también A. CANELLAS, «El notariado en España hasta el siglo XIV: estado de la cuestión", en Notariado público y documento privado: de los orígenes al siglo XIV. Actas del VII Congreso Internacional de Diplomática, Valencia, 1986, Valencia 1989 , p. 115, quien opina que estos notarios debían limitarse a escriturar negocios sustanciados en la curia episcopal, lo cual no parece que se respetase siempre, por ello, y para evitar fricciones entre estos notarios y los escribanos comunales y reales, ya las cortes de Valladolid de 1322 , les había prohibido inmiscuirse en los negocios seglares. Cortes de los antiguos reinos de León y de Castilla, Real Academia de la Historia, I, Madrid 1861, p. 365.

63 "...fincando soberanas y por escrevir diez fojas deste dicho libro", aunque ya sabemos que fueron arrancadas en un momento posterior.

64 Todos los folios, en el verso y recto, se encuentran cerrados en la parte inferior por una línea que empieza y termina en un signo, especie de clave de sol, interrumpida por la firma y rúbrica del notario, ligeramente desplazada hacia la derecha. La caja de escritura del primer folio está enmarcada por líneas trazadas por el propio escribano, y todo hecho con otra pluma y tinta más clara a la empleada en el documento. 
Gil Álvarez, respaldado por el aval de algunas joyas que los deudores han empeñado y que se custodian en el tesoro catedralicio. Este compromiso de arrendamiento es refrendado por las firmas y rúbricas de los miembros del cabildo, entre las que se encuentra la del propio Gil Álvarez, y cerrado por el notario como testigo cualificado.

\section{TRANSCRIPCIÓN ${ }^{a}$}

Este es el libro de cómmo se deben pagar las debdas para quitar la eglesia ${ }^{b}$.

Libro sellado de actas capitulares. Desde la era 1367. Año 1329. Noviembre, $24^{\mathrm{c}}$.

Viernes, veynte et quatro días de noviembre, era de mille trezientos sessenta et siete annos, llegado el cabilldo de la eglesia de Cuenca a son de la campana mayor, segund que es uso et costumbre de la eglesia de Cuenca, sennaladamente para librar la dicha eglesia dell entredicho en que está por el debdo que fue abenido con el camarero de nuestro sennor el papa don Johán XXII, que agora es, por çinquanta mille maravedís, por razón de los fructos et las rendas dell obispado que reservó el dicho sennor papa para la su cámara al tiempo que la dicha eglesia vacava por muerte de don Pascual, obispo que fue della, en el qual tiempo fue electo don Pero Martínez, deán que fue de la dicha eglesia, obispo de Évora que agora es, la qual reservaçión de los dichos fructos fizo el dicho sennor papa fasta el día que tovo por bien de proveer de la dicha eglesia a don

a Normas seguidas en la edición: La grafía se mantiene fiel al documento con la mayor exactitud posible, aunque se actualiza el criterio en cuanto al uso de mayúsculas, minúsculas y normas de acentuación y puntuación. Las diferentes clases de $i$, larga o corta, se transcriben por $i / j$ según su valor vocal o semiconsonante, a la vez que mantenemos la $y$ con valor vocálico. Se regulariza el uso de $u / v$ según su valor en el texto. La $c$ se mantiene, así como la geminación de consonante en cualquier situación, excepto al principio de palabra, si no es $/$. Con el fin de unificar, el signo general de abreviatura que señala ausencia de nasal antes de $b$ y $p$ se ha transcrito siempre por $\mathrm{m}$, porque así aparece frecuentemente antes de $\rho$, aunque antes de $b$ aparece más o menos en la misma proporción cuando no se omite. El signo tironiano se transcribe siempre por et, ya que así se utiliza la conjuntiva cuando se desarrolla. Hemos separado las palabras unidas, excepto las contracciones usuales de preposición y pronombie, y desarrollado las abreviaturas. Los errores del amanuense, tachaduras o interlineales por omisión, se escriben entre $\backslash /$ indicándolo en nota, mientras que las duplicaciones del texto se indicarán entre $<>$. Para incidir lo menos posible en el texto, no se indican los calderones ni los signos que cierran párrafo. Por igual motivo no hemos indicado el cambio de renglón, aunque sí el cambio de folio con doble raya, acompañado del número correspondiente y su posición de recto o vuelto: $/ /^{1 \mathrm{v}}$.

b Letra coetánea, en la portada.

c Letra del s. XVIII: en la portada. 
fray Estevan, obispo que fue dende, de los quales fructos et rendas fue recabdador don Remón Ebrart, mandadero del papa, entonçe tesorero, después deán et agora obispo de Coymbra, et seyendo presentes perssonas et canónigos los que aquí dirá:

Del coro del obispo:

Gil Álvarez, arçidiano de Cuenca.

Sancho Domínguez, chantre.

Nicolás López, arçidiano de Alarcón.

Johán Martínez, tesorero.

Matheo Pérez.

Gonçalo Garçía.

Garçi Ximénez.
Del coro del deán:

Ferrand Garçía, deán.

Ruy López, arçidiano de Huepte.

Sancho López, arçidiano de Moya. Gyllem Vidal, maestrescuella.

Sancho Pérez.

Garçi Mártínez.

Johán Pérez, arçipreste.

Sancho Martínez // ${ }^{\text {ir }}$

Et porque fallaron que era çierto que desta dicha quantía de los çinquanta mille maravedís pagaron et eran ya pagados a la cámara de nuestro sennor el papa los treze mille maravedís, para fazer paga complida de los treynta et siete mille maravedís que fincan, después de muchos tractados, acordaron todos de una voluntad que algunos debdos que devien algunos de la eglesia al cabilldo et en común, que fuessen tenudos de los pagar para esto a çierto término, segund que adelante se contiene:

Primeramente fallaron que Ferrand Garçía, deán de la eglesia de Cuenca, deve a la dicha eglesia en común de un cavallo que ofreçió all altar de la dicha eglesia, don Remón Ebrarte, mandadero del papa, para una vestimienta fecha a sus sennales, quatroçientos e setenta maravedís, et ordenaron que estos dichos maravedís fuessen para esta paga, et el cabilldo que finque obligado a lo que el dicho deán era tenudo de complir por los dichos maravedís. Otrossí fallaron que deve el dicho deán a Johán Gonçález, canónigo que fue de Cuenca, que Dios perdone, nueveçientos maravedís por el vestiario de Alarcón de la era de mille trezientos et sessenta et quatro, et porque el dicho Johán Gonçález devíe et deve al dicho cabilldo seysçientos maravedís por la fiesta de sanct Johán de mayo que se él obligó de fazer de seys capas para en siempre. Otrossí que el dicho Johán Gonçález devíe trezientos para su aniversario, segund que era tenudo por la constituçión de la eglesia <eglesia>, ordenaron que estos nueveçientos maravedís de la fiesta et aniversario sobredichos, que los diesse el deán para esta paga, et el cabilldo que den carta al deán commo los toman para esto, $/ /{ }^{1 \mathrm{v}}$ et del redrar ende $\sin$ danno de quien quier que ge 
los demandasse en algún tiempo en todo o en parte. Otrossí fallaron que deve el dicho deán al dicho cabilldo por el vestiario de Moya de Garçi Martínez, canónigo, de la era de sessenta et dos, trezientos maravedís que se obligó de pagar por ell aniverssario del padre et de la madre del dicho Garçí Martínez, et mandaron e ordenaron que estos dichos trezientos maravedís que fuessen para esta paga. Otrossí fallaron que deve el dicho deán al dicho cabilldo, por la fiesta de sanct Estevan que él faze de seys capas en la dicha eglesia, trezientos maravedís, et mandaron et ordenaron que estos dichos trezientos maravedís que los diesse el deán para esta paga, et que el dicho cabilldo que finquen obligados para en siempre de fazer la dicha fiesta de seys capas. Otrossi se obligó el deán de pagar para esta dicha paga treynta maravedís, pero que el cabilldo quel sea tenudo de ge lo reçebir en cuenta.

Suma de todo lo que el deán a de dar para esta paga, dos mille maravedís.

Otrossí fallaron que Gil Álvarez de Albornoz, arçidiano de Cuenca, devíe al dicho cabilldo en común mille maravedís que tomó prestados de los maravedís que ell obispo de Évora envió a la eglesia de Cuenca con Lop Álvarez, su criado, segund que adelante se contiene, et mandaron et ordenaron que estos mille maravedís fuessen para esta dicha paga, et fecha paga destos mille maravedís quel diessen la su carta que tienen de conosçimiento en esta razón, que está en el tesoro.

Otrossí fallaron que devíe el dicho arçediano $/ /^{2 r}$ seyçientos maravedís para la fiesta de sanct Sadorní, que faze de seys capas en la dicha eglesia, et mandaron et ordenaron que estos dichos seyçientos maravedís que los diesse ell arçidiano para esta paga, et el cabilldo reçibieron en su reffitor la dicha fiesta, de guisa que sean tenudos de la fazer de seys capas para en siempre. Otrossí fallaron que devíe el dicho arçidiano al cabilldo de la dicha eglesia, dos marcos de plata por la constituçión jurada que deve dar todo aquel que ha nueva dignidad en la eglesia de Cuenca ${ }^{d}$. Et estos marcos fueron puestos en çient et sessenta maravedís, et mandaron et ordenaron que estos dichos cient et sessenta maravedís que los diesse ell arçidián para esta paga.Otrossí, el dicho Gil Álvarez, arçidiano, de su propria voluntad, se obligó de pagar para esta dicha paga mille maravedís en recompenssaçión et en emienda de algunos diezmos que falleçió de pagar Garçi Álvarez de Albornoz, su padre, del diezmo de Cannamares et

¿ Se refiere a otro apartado de la misma constitución del obispo Fray Esteban a la que hemos aludido en páginas anteriores. Ver nota 52. 
de Tragazete et dell Aldehuela et de otros lugares. Otrossí se obligó de pagar el dicho arçidiano nuevecientos maravedís por Sancho Martínez, canónigo, del tiempo que fue reffitorero, que devíe cobrar el cabilldo de la dicha eglesia de los bienes de don Alffonso Martínez, arçidiano que fue de Cuenca, que Dios perdone.

Suma de todo esto que deve pagar el dicho Gil Álvarez, arçidiano Ique fue/ ${ }^{\text {e }}$ de Cuenca, para esta paga, tres mille seyçientos et sessenta maravedís // ${ }^{2 v}$.

Otrossí fallaron que Sancho Domínguez, chantre de la eglesia de Cuenca, que devíe al cabilldo de la dicha eglesia trezientos maravedís por la fiesta de sanct Eugenio que él faze en la dicha eglesia de seys capas, et mandaron et ordenaron que fuesse tenudo el dicho chantre de dar et pagar, para esta dicha paga, estos dichos trezientos maravedís.

Otrossí fallaron que Ruy López, arçidiano de Huepte, que devíe al refitor de la dicha eglesia para la maytinada de la era de mille trezientos sessenta et seys annos mille maravedís, et mandaron et ordenaron que el dicho arçidiano de Huepte fuesse tenudo de dar et pagar, para esta dicha paga, los dichos mille maravedís.

Otrossí fallaron que Sancho Martínez, canónigo, deve a la dicha eglesia, quatroçientos maravedís para una capa de seda que deve dar cada un canónigo que nuevamente viene a la dicha eglesia por la constituçión que es jurada en esta razón, et mandaron et ordenaron que el dicho Sancho Martínez fuesse tenudo de dar et pagar, para esta dicha paga, estos dichos quatroçientos maravedís.

Otrossí fallaron que Pero Viceynte, canónigo de la dicha eglesia, por essa misma constituçión et por essa misma razón, que deve a la dicha eglesia otros quatroçientos maravedís, et mandaron et ordenaron que el dicho Pero Viceynte fuesse tenudo de dar et pagar, para esta dicha paga, estos dichos quatroçientos maravedís // ${ }^{3 r}$.

Otrossí fallaron que Gonçalo Garçía, canónigo, por essa misma constituçión et por essa misma razón, que deve a la dicha eglesia otros quatroçientos maravedís, et mandaron et ordenaron que el dicho Gonçalo Garçía fuesse tenudo de dar et pagar, para esta dicha paga, estos dichos quatroçientos maravedís.

Otrossí fallaron que Matheo Pérez, canónigo de Cuenca, deve al cabilldo de la dicha eglesia mille maravedís de los maravedís que envió a la

e Tachado. 
eglesia de Cuenca don Pero, obispo de Évora, con Lop Álvarez, su criado, segund adelante se contiene, et mandaron et ordenaron que el dicho Matheo Pérez fuesse tenudo a dar et pagar, para esta dicha paga, los dichos mille maravedís.

Otrossí fallaron que Gil Martínez Daguilera, et por la dicha constituçión de las capas et por essa misma razón que los otros canónigos nuevos, que deve a la dicha eglesia quatroçientos maravedís, et mandaron et ordenaron que el dicho Gil Martínez fuesse tenudo de dar et pagar, para esta dicha paga, los quatroçientos maravedís. Et en esto conssintió el dicho Gil Martínez et rogó a Ferrand Garçía, deán de Cuenca, que seellasse et so scriviesse la carta que enviavan all obispo con esta razón, segund adelante se contiene.

Otrossí fallaron que Johán Martínez, tesorero de la dicha eglesia, deve al reffitor çient et sessenta et dos maravedís de la maytinada dell anno de sessenta et siete annos, et mandaron et ordenaron que el dicho tesorero fuesse tenudo de dar et pagar, para esta dicha paga, estos dichos çient et sessenta et dos maravedís // ${ }^{3 v}$. Otrossí fallaron que el dicho tesorero devíe al cabilldo de la dicha eglesia dos marcos de plata que deve dar todo aquel que nuevamente ha dignidad en la eglesia de Cuenca, que fueron puestos en çient et sessenta maravedís, et mandaron et ordenaron que el dicho tesorero fuesse tenudo de dar et pagar, para esta dicha paga, estos clichos çient et sessenta maravedís.

Suma de todo lo que ha de dar el tesorero para esta paga, trezientos veynte et dos maravedís.

Otrossí fallaron que Sancho Gil, raçionero de la dicha eglesia, que deve al reffitor de la dicha eglesia de la missada dell anno de sessenta et siete, trezientos maravedís, et mandaron et ordenaron que el dicho Sancho Gil fuesse tenudo de dar et pagar, para esta dicha paga, estos dichos trezientos maravedís.

Otrossí ordenaron et acordaron por el dicho cabilldo que estos sobredichos debdores et cada uno dellos se obligassen de pagar los dichos debdos a día çierto para la dicha paga, segund nuestro sennor ell obispo toviesse por bien, et de su propia voluntad et de çierta sçiençia obligáronsse a ello por cabilldo. Et sobresto enviaron su carta all obispo fecha en esta guisas:

Al mucho onrrado padre e sennor don Oddo, por la graçia de Dios obispo de Cuenca, nos Ferrand Garçía, deán, Gil Álvarez, arçidiano de Cuenca, Ruy López, arçidiano de Huepte, Sancho Domínguez, chantre, Johán Martínez, tesorero, Matheo Pérez, Sancho Martínez, Pero Viceynte, 
Gonçalo Garçía, Gil Martínez Daguilera, canónigos, et Sancho Gil, raçionero de la eglesia de Cuenca, besamos vuestras manos et nos encomendamos en vuestra graçia. Sennor, $/ /^{4 r}$ sobre lo que fablastes en el cabilldo de vuestra eglesia et nos enviastes por muchas vegadas rogar et amonestar por vuestras cartas que catéssemos alguna buena manera porque la eglesia de Cuenca fuesse librada de la sentençia et del entredicho len/ ${ }^{\ddagger}$ que está, fiziemos muchos cabilldos et después de muchos tractados fue delibrado et acordado que de algunos debdos que yo, Ferrand Garçía, deán sobredicho, devía al cabilldo en común, que diesse et pagasse para esto dos mille maravedís. Otrossí, que yo, Gil Álvarez de Albornoz, arçidiano de Cuenca, diesse et pagasse para esto tres mille seyçientos et sessenta maravedís, et yo, Ruy López, arçidiano de Huepte, mille maravedís, et yo, Sancho Domínguez, chantre, trezientos maravedís, et yo, Johán Martínez, tesorero, trezientos et veynte et dos maravedís, et yo, Matheo Pérez, canónigo, mille maravedís, et yo, Sancho Martínez, canónigo, quatroçientos maravedís, et yo, Pero Viceynte, canónigo, quatroçientos maravedís, et yo, Gonçalo Garçía, canónigo, quatroçientos maravedís, et yo, Gil Martínez Daguilera, canónigo, quatroçientos maravedís, et yo, Sancho Gil, raçionero, trezientos maravedís. Et por vos dar a entender que es nuestra voluntad de pagar estos debdos sobredichos porque la eglesia salga de la sentençia en que está, obligámosnos por cabilldo, cada unos de nos, de pagar cada uno esto que dicho es el día de Pascua Mayor, esta primera que viene, so pena de las raçiones et de las pitanças, et si a este plazo non pagásemos, que de la Dominica de Quasimodo adelante que nos podades susspender de offiçios et de benefiçios, et si desta Dominica de Quasimodo non pagásemos esto que dicho es fasta la otra Dominica primera siguiente, que nos podades escomulgar. Et para reçebir por nos et en nuestro nombre et de cada uno de $/ /{ }^{4 v}$ nos estas penas et sentençias, quier de agora quier de entonçe, bien commo vierdes que se deve mejor fazer, nos, e cada uno de nos, fazemos nuestro procurador para esto, que non entendemos revocar en ningún tiempo, a Guillem Vidal, maestrescuela de Cuenca. Et desto vos enviamos esta nuestra carta abierta et seellada con nuestros seellos et so scripta de nuestros nombres, et porque yo, Gil Martínez Daguilera, estava de camino, rogué a Ferrand Garçía, deán de Cuenca, que seellasse et so scriviesse esta carta por él et por mí, et a Guillem Vidal, maestrescuela, que fuesse mi procurador, assí commo de los otros, para esto.

Dada en el cabilldo de la eglesia de Cuenca, treynta días de deziembre, era de mille et trezientos et sessenta et siete annos.

Entre renglones. 
Desde el viernes susodicho fasta el día de la data desta carta, fueron fechos muchos cabilldos sobresto fasta que acordaron de fazer et de envíar all obispo la dicha carta, et, por ende, la dicha carta fue dada después del dicho viernes, a treynta et seys días. Et este día que la dicha carta fue dada juraron todos los que en la dicha carta se contienen por cabilldo, de non revocar la procuraçión que otorgaron al dicho maestrescuela en esta razón, salvo el dicho Gil Martínez Daguilera que non era presente.

Suma que monta todo lo que deven et an de pagar los sobredichos que en la dicha carta se contienen, diez mille et çient et ochenta et dos maravedís.

Otrossí fallaron que algunos otros canónigos, sin los que en la dicha carta se contienen, que ovieron las calongías nuevamente en la eglesia de Cuenca et deven sendas capas de seda de preçio de cada quatroçientos maravedís por la constituçión sobredicha, et ordenaron et mandaron que cada uno dellos fuesse tenudo de pagar los dichos maravedís para esta $/ /{ }^{5 r}$ paga, et porque los que eran abssentes de la eglesia non pudieron fazer sobre sí la dicha obligaçión que en la dicha carta se contiene, ordenaron et mandaron que vendiessen de las rendas de sus benefiçios de cada uno fasta en complimiento de los dichos mille maravedís. Et los fructos de los dichos benefiçios fueron luego vendidos por el pregonero et por ell almoneda antel portal de la eglesia de Cuenca, segund que es uso et costumbre de la dicha eglesia, en la manera que daquí adelante se sigue:

Primeramente, porque fallaron que Garçi Ximénez, canónigo, devía a la dicha eglesia quatroçientos maravedís para una capa de seda por la constituçión sobredicha, ordenaron et mandaron que estos dichos quatroçientos maravedís que fuesse tenudo de los dar et pagar para esta dicha paga. Et luego, en presente por cabilldo, otorgolo assí el dicho Garçi Ximénez et dio luego por cabilldo por debdor et manero, que los pagasse por él al plazo que el deán et el cabilldo toviessen por bien, a Pero Martínez de Soria. Et luego el dicho Pero Martínez obligó assí et a sus bienes de pagar los dichos quatroçientos maravedís por el dicho Garçi Ximénez, et desde agora reçibió sobre sí sentençia de escomunión el dicho Pero Martínez si non pagasse los dichos quatroçientos maravedís por el dicho Garçi Ximénez, fasta el día de Navidat primera que viene, que será en la era de mille et trezientos e sessenta e siete annos. La cual sentençia puso en él desde agora, segund forma de derecho, el dicho Ferrand Garçía, deán de Cuenca. Et después, con acuerdo de todo el cabilldo, el dicho plazo de la dicha sentençia alongolo el dicho deán fasta mediada Quaresma $/ /^{5 \mathrm{v}}$.

Otrossí fallaron que Garçi Martínez, canónigo, deve a la dicha eglesia dozientos et quarenta maravadís de la meytad del vestiario de Moya de 
Pero Viceynte, canónigo, del fructo de la era de sessenta e seys que ovo de pagar por la Trinidat de la era de sessenta et siete, et mandaron et ordenaron que el dicho Garçi Martínez fuesse tenudo de pagar los dichos dozientos et quarenta maravedís para esta paga. Et luego desde agora el dicho deán puso en él sentençia de escomunión si non pagasse los dichos dozientos et quarenta maravedís fasta mediada Quaresma primera que viene.

Otrossí fallaron que Fortún Sánchez, canónigo de Cuenca, devíe a la dicha eglesia quatroçientos maravedís por la dicha constituçión, et porque era abssente de la eglesia et non paresçíe ningún su procurador por él et fallaron, otrossí, que avíe en el obispado de Cuenca estos benefiçios que aquí se siguen: Belmonte de Alarcón, Monteagudo dell Obispado, Mariana, raçiones prestameras, Barvalimpia, Cannamares et Fuentes Claras, préstamos, et Cannaveras, raçión prestamera, mandaron vender los fructos destos dichos benefiçios por la dicha almoneda, et fueron vendidos desta guisa: la raçión prestamera de Monteagudo, del fructo de la era de sessenta et ocho, sacola Guillem Vidal, maestrescuela, por çient et veynte maravedís, plazo a Pascua de Navidat primera que viene, que es en la era de sessenta et siete. Et después, por acuerdo del cabilldo, este plazo fue alongado al primer día de Quaresma primera que viene, et reçibió sobre sí sentençia de escomunión puesta por el dicho deán si a este plazo non pagase.Item, el fructo de la dicha raçión dell anno de sessenta et nueve primero que viene, sacolo por la dicha almoneda Martín Ferrández, criado del deán, [et] maestre Domingo, //6r por çient maravedís, plazo al primer día de Quaresma.Item, el fructo de la raçión prestamera de Mariana dell anno de sessenta et siete, sacolo por la dicha almoneda el dicho Guillem Vidal, maestrescuela, por quarenta et çinco maravedís, plazo al dicho primer día de Quaresma.Item, el fructo de los préstamos de Fuentes Claras et de Cannamares de la era de sessenta et siete, sacolo Matheo Pérez, canónigo, por veynte maravedís, plazo al dicho primer día de Quaresma.Item, el fructo del préstamo de Barvalimpia de la era de sessenta e siete, sacolo Diego Ferrández, maestro de la obra, por diez maravedís, plazo al dicho primer día de Quaresma.Item, el fructo de la raçión prestamera de Cannaveras de la era de sessenta e siete, sacolo Johán Sánchez, criado de Sancho Pérez, canónigo, por sessenta maravedís, plazo el primer día de Quaresma. Fincan por vender el fructo de la raçión de Belmonte de Alarcón. Item, el fructo de la su raçión prestamera de Arcas de la era de sessenta et siete, sacolo Johán Martínez, tesorero, por quarenta maravedís, plazo al dicho primer día de Quaresma. 
Suma que montan todos estos fructos que fueron vendidos del dicho Fortún Sánchez, trezientos et lveynte et çinco/ ${ }^{g}$ noventa et çinco maravedís, et por los maravedís que fincan et por carreras et lavores, fincan que se ha de vender los fructos del beneffiçio de Belmonte de la era de sessenta e siete.

Otrossí fallaron que Johán Gonçález, chantre de Córdova, canónigo de la eglesia de Cuenca, deve a la eglesia de Cuenca, por essa misma constituçión et por essa misma razón, quatroçientos maravedís, et fallaron, otrossí, que avíe en el obispado de Cuenca // ${ }^{\text {} v}$ estos benefiçios: Vascunnana con La Muela, Ell Olmeda de la Cuesta, Salmerón, La Parra, Sanct Pedro de Huepte, Sancta María de Huclés. El fructo de los benefiçios de Vascunnana con La Muela, sacolo Matheo Pérez, canónigo, por veynte maravedís, plazo al primer día de Quaresma sobredicha; el beneffiçio dell Olmeda de la Cuesta del fructo de la era de sessenta et siete, sacolo Diego Ferrández, maestro de la obra, por diez maravedís, plazo al primero día de Quaresma. Item, el fructo del beneffiçio de Salmerón de la era de sessenta e siete, sacolo Guillem Vidal, maestrescuela, por çient et çinquanta maravedís, plazo al dicho primero día de Quaresma. Item, el fructo del beneffiçio de La Parra de la era de sessenta et siete, sacolo Martín Sánchez, clérigo de Sanct Estevan, por treynta maravedís, plazo al dicho primer día de Quaresma; el fructo del benefiçio de Sanct Pedro de Huepte de la era de sessenta et siete, sacolo Gil Álvarez, arçidiano de Cuenca, por çient maravedís, plazo al dicho primer día de Quaresma. Item, el fructo del benefiçio de Sancta María de Uclés de la era de sessenta et siete annos, sacolo Guillem Vidal, maestrescuela, por quarenta maravedís, plazo al primer día de Quaresma. Item, el fructo del dicho beneffiçio de Sant Pedro de Huepte de la era de sessenta et ocho, sacolo el dicho arçidiano de Cuenca por setenta maravedís, al dicho plazo.

Suma que montan los fructos destos dichos benefiçios del dicho chantre, quatroçientos et veynte maravedís, los quatroçientos para esta paga et los veynte para lavores et carreras. $/ /^{7 r}$.

Otrossí fallaron que Guillem Bernalte, canónigo de Cuenca, deve a la eglesia por essa misma constituçión et por essa misma razón, quatroçientos maravedís, et ordenaron et mandaron que los diesse para esta paga,et Pero Garçía, sobrino del chantre Sancho Domínguez, procurador del dicho Guillem Bernalte, obligosse de pagar por él estos dichos quatroçientos maravedís, et Ferrand Garçía, deán sobredicho, desde agora puso en él

g Tachado. 
sentençia de escomunión, segund forma de derecho, si non pagasse los dichos quatroçientos maravedís a mediada Quaresma primera que viene.

Suma que monta lo que an a dar estos canónigos sobredichos, con çinco maravedís que se an de cobrar del benefiçio de Belmonte del dicho Fortún Sánchez, mille ochoçientos et quarenta maravedís.

Otrossí, porque la calongía que fue de don Pedro, cardenal, vaca en corte, et qualquier que la aya deve pagar quatroçientos maravedís por la dicha constituçión, ordenaron et mandaron que estos dichos quatroçientos maravedís sean para esta paga et que se vendan los fructos de los benefiçios para esto, et mandaron luego vender estos benefiçios: en Sanct Clemeynte, raçión prestamera, en La Ossa, raçión prestamera, en Sotos, raçión prestamera, et fueron vendidos et sacados por ell almoneda antel portal de la eglesia de Cuenca desta guisa: el fructo de la raçión de Sanct Clemeynte dell anno de sessenta et siete, que agora passó, sacolo Sancho Sánchez, compannero de la eglesia de Cuenca con esta condiçión: que si don Johán lo mandara tomar o embargar que oviesse el fructo deste anno de sessenta et ocho por çiento et quinze maravedís; el fructo del benefiçio de La Ossa sacolo Pero Martínez, sochantre, notario público de la // ${ }^{7 v}$ eglesia de Cuenca, con essa misma condiçión, por çinquanta maravedís; el fructo del benefiçio de Sanct Viceynte de Cuenca de la era de sessenta et ocho, sacolo Jayme López, clérigo dende, por çient maravedís; el fructo del benefiçio de Sotos de las eras de sessenta et siete et de sessenta et ocho, sacolo Johán Domínguez de Sotos por sessenta maravedís; el fructo de Sanct Clemeynte et de La Ossa de la era de sessenta et ocho, si de los annos de ante fuesse desembargados, si non, de sessenta et nueve, sacolo Pero Sánchez, compannero, por çient et çinquanta maravedís. Plazo de todo a mediada Quaresma, et el deán Ferrand Garçía puso en ellos sentençia de escomunión si al dicho plazo non pagassen, segund dicho es.

Suma que montan los dichos fructos destos dichos benefiçios et lo que fueron vendidos, quatroçientos et setenta et çinco maravedís, los quatroçientos para esta paga, et los setenta et çinco maravedis para semanas et lavores del tiempo de Pero Sánchez, reffitorero.

Otrossí, acordaron que Johán de Luna et Nicolao de Çetano, canónigos de Cuenca, que an buena renda en la eglesia et en el obispado de Cuenca et de cada día se ayudan de las rendas de la eglesia et nunca la vinieron a servir nin la sirven, que paguen para esto cada quatroçientos maravedis, que son ochoçientos maravedís, et para esto se obligó luego por cabilldo don Domingo, procurador de Johán de Luna, de pagar por el dicho Johán de Luna al dicho plazo de mediada Quaresma quatroçientos maravedís, et 
por los otros quatroçientos maravedís mandaron luego vender de los benefiçios de Nicolao estos: Vellinchón, Torralva et Sancto Domingo de Cuenca, raçiones prestameras. Et sacáronlas por la dicha almoneda: $/ /{ }^{8 r} \mathrm{el}$ fructo del benefiçio de Vellinchón de la era de sessenta et siete Pascual Sánchez, raçionero de la eglesia de Cuenca, por çient maravedís; el fructo del benefiçio de Torralva de la era de sessenta et siete Gil Álvarez, arçidiano de Cuenca, por lquatroçientos maravedís/ ${ }^{\mathrm{h}}$ çiento et diez maravedís, al dicho plazo de mediada Quaresma; el fructo del benefiçio de Sancto Domingo de Cuenca de la era de sessenta et siete el dicho Pascual Sánchez, por çient maravedís. Et porque esta vendida non cumplía, vendieron otra vez el fructo del dicho benefiçio de Torralva de la era de sessenta et ocho, sacolo el dicho arçidiano de Cuenca por noventa maravedís.

Suma de la vendida destos beneffiçios del dicho Nicolao quatroçientos maravedís.

Otrossí fallaron que herederos de Pero Sánchez, fijo de Johán Sánchez, deven a la dicha eglesia çient et noventa et siete maravedís, et an los a pagar Johán Sánchez, capellán, su fijo, et Pero Martínez de Soria, su yerno, et mandaron et ordenaron que esos dichos çiento noventa et siete maravedís que fuessen para esta paga, et que el deán, o qui toviere sus vezes, que les apremie et les entregue que paguen fasta el primer día de Quaresma primera que viene.

Otrossí fallaron que Diego Ferrández del Castiello deve trezientos maravedís del vestiario de Munno Pérez, abbad de Sanct Ander, del anno de sessenta et tres, et mandaron et ordenaron que fuessen para esta paga los dichos trezientos maravedís.// ${ }^{8 v}$.

Otrossí fallaron que Apariçio Pérez, canónigo, clérigo que fue de Sanct Nicolás de Cuenca, que deve trezientos maravedís por la fiesta de Sanct Nicolás de mayo que fazíe de quatro capas, et mandaron et ordenaron que fuessen para esta paga estos dichos trezientos maravedís, et el deán, o qui toviere sus vezes, que faga entregar en sus bienes.

Otrossí fallaron que Savastián Pérez, refitorero, et Pero Sánchez, pitançero, que fueron, deven dar recabdo de seysçientos maravedís que dio Guillem Vidal, maestrescuela, por la fiesta de Sanct Bernaldo que faze de seys capas, et mandaron et ordenaron que estos dichos seysçientos maravedís fuessen para esta paga, et destos dichos seysçientos maravedís

n Tachado. 
ha de dar recabdo Pero Sánchez, refitorero sobredicho, desta guisa: ha de pagar por Ponçe Díaz don Yánnez el Lechiguero, su procurador, dozientos et veynte et dos maravedís al dicho plazo, so pena de la dicha sentençia que puso luego en él el deán, et los otros trezientos setenta et ocho que fincan ha los de dar el dicho Pero Sánchez de los benefiçios de Guillem Bernalte, que fueron vendidos para esto por semanas et lavores et carreras et una yantar, segund que en el libro del dicho Pero Sánchez, refitorero, se contiene. Todos los sobredichos que sacaron por la dicha almoneda los fructos de los dichos beneffiçios, assí personas, canónigos, clérigos et legos, reçibieron sobre sí sentençia de escomunión puesta desde agora por el dicho deán si non pagassen a los dichos plazos. $/ /^{9 r}$.

Otrossí fallaron que don Pedro, obispo de Évora, envió al cabilldo de la eglesia de Cuenca con Lop Álvarez, canónigo, su criado, çinco mille maravedís a una parte, et destos tomó Gil Álvarez, arçidiano de Cuenca Vos/ Idos/ ' mille maravedís que dessuso se contienen, et los otros quatro mille maravedís están en el tesoro, et ordenaron et mandaron que estos dichos quatro mille maravedís que fuessen para esta paga.

Otrossí fallaron que el dicho obispo de Évora envió a la dicha eglesia con Matheo Pérez, canónigo, et con Pascual Pérez, canónigo, clérigo de Sanct Pedro, su procurador, quatro mille maravedís, et destos dichos quatro mille maravedís ha de dar Matheo Pérez mille maravedís para la dicha paga, segund dessuso se contiene. Otrossí ha de dar el dicho Matheo Pérez trezientos maravedís para esta dicha paga, quitos cient maravedís quel quitaron el deán et el cabilldo sobre los quinientos maravedís quel dieron paral camino quando le inviaron all obispo de Évora. Destos dichos quatro mille maravedís tomaron Savastián Pérez, compannero, et Miguel Pérez, obrero, mille et seyçientos maravedís para reparar la casa et la presa de los molinos de Olivares, et deven dar ende cuenta et paga.

Suma con los quatro mille maravedís que están en el tesoro et con mille maravedís que ha de pagar Gil Álvarez, arçidiano de Cuenca, para esta paga, et con otros mille maravedís que deve pagar Matheo Pérez, canónigo, para esta dicha paga, et con trezientos mavedís que ha de pagar el dicho Matheo Pérez para esto, et con los çient maravedís quel dieron el cabilldo sobre los quinientos para la mandadería, et con Vos/k mille et seysçientos maravedís que tomaron los dichos Savastián Pérez et Miguel Pérez, ocho mille maravedís.// ${ }^{9 v}$.

Entre renglones.

Tachado.

Entre renglones. 
Et porque fallaron que el dicho obispo de Évora enviara a la eglesia de Cuenca nueve mille maravedís, que se pagassen desta guisa: por las azennas de Córdova que vendió el dicho obispo porque son obligados a la dicha eglesia, la heredad del Villar del Puerto et otros bienes del dicho obispo que obligó para esto seyendo benefiçiado en la eglesia de Cuenca, siete mille maravedís. Otrossí, por ell aniverssario de María Ferrández, muger de Diego Martínez de la Cámara, que devíe el dicho obispo mille maravedís. Otrossí, por los otros mille maravedís que deve el dicho obispo a la eglesia de Cuenca del tiempo que Sancho Martínez, canónigo, fue refitorero, fizieron llamar a cabilldo al dicho Pascual Pérez, canónigo et procurador del dicho obispo, et pidiéronle los mille maravedís que menguavan del tiempo del dicho Sancho Martínez, refitorero, para cumplimiento de los dichos nueve mille maravedís, et el dicho Pascual Pérez dixo que commo quiere que primeramente ell obispo de Évora le mandó que diesse los dichos mille maravedís del tiempo del dicho Sancho Martínez para esto, et después oviera mandado en cómmo desproviesse los mille maravedís et más en cosas que teníe ell obispo, que era mayor su pro et que las despendiera en aquellas cosas que ell obispo le enviara mandar et que non era a más tenudo, et que por estos mille maravedís que fincavan para complimiento de los dichos nueve mille maravedís que fiziessen entrega en bienes del dicho obispo de Évora, et quel plazíe que se fiziesse la dicha entrega. Et luego ordenaron et mandaron que el deán, o qui toviesse sus vezes, que entregue en bienes del dicho obispo, en los mejor parados que fallaren, muebles o rayzes, fasta en quantía de los dichos mille maravedís. Et por los trezientos maravedís que fincaron en el dicho Matheo Pérez mandaron et ordenaron que el dicho Matheo Pérez paga $/ /{ }^{10 r}$ sse los dichos trezientos maravedís para esta paga, fasta Pascua Florida primera que viene. El deán, desde agora, puso en él sentençia de escomunión si al dicho término non pagasse los dichos trezientos maravedís.

Suma que monta esto que dicho es desde la otra suma fasta aquí, sin mille et seysçientos maravedís que an a dar cuenta Matheo Pérez et Savastián Pérez, los sobredichos, siete mille ochoçientos noventa et siete maravedís.

Otrossí ordenaron et mandaron que de los dineros que deven algunos debdores a la eglesia del tiempo lde/ "lque/ m Sancho Martínez fue refitorero, de los mejor pagados et de los que más ayna se pudiessen aver, que se diessen et se pagassen para esto dos mille maravedís.

Tachado.

m Entre renglones. 
Otrossí, el dicho don Pedro, obispo de Évora, envió dezir al dicho cabilldo con Matheo Pérez que les queríe prestar para esta paga seys mille maravedís sobre los sus molinos nuevos, et mandaron et ordenaron que los dichos molinos que se empennassen para esto, et estos seys mille maravedís que fuessen para esta paga.

Otrossí pidieron por merçed antel sennor ell obispo don Oddo, et el dicho obispo con el cabilldo acordó que se tomassen para esto los terçihuelos de las eglesias de ell obispado, et el obispo et el cabilldo pidieron por merçed a don Johán, fijo dell infante don Manuel, que toviesse por bien de consentir que passasse esto assí en la su tierra, et don Johán tóvolo assí por bien, et mandó dar su carta en esta razón que traxo a la eglesia con las otras el deán Ferrand Garçía, et está en el tesoro. Et después Guillem Vidal, maestrescuela, dixo en cabilldo $/ /^{10 v}$ de parte dell obispo, que tenía por bien ell obispo de dar de los dichos terçihuelos para esto quatro mille maravedís, pero que se contassen mille et seyçientos maravedís que él era tenudo de dar para ornamentos a la eglesia por la costituçión en los dichos quatro mille maravedís.

Otrossí fallaron que Bernardo Pérez et Sancho Gil deven a la dicha eglesia de la missada que rendaron dell anno de sessenta et ocho trezientos maravedís, et mandaron que fuessen para esta paga estos dichos trezientos maravedís.

Otrossí fallaron que Gil Álvarez, arçidiano de Cuenca, et Sancho Pérez, canónigo, deven a la dicha eglesia mille maravedís de la maytinada que rendaron ell anno de sessenta et ocho, et mandaron que fuessen para esta paga estos dichos mille maravedís.

Otrossí fallaron que Pero Martínez de Soria deve a la dicha eglesia trezientos et çinquanta maravedís del vestiario de Gómez Pérez, et mandaron que fuesse tenido el dicho Pero Martínez de dar para esta dicha paga los dichos trezientos et çinquanta maravedís.

Otrossí fallaron que las capellanías que se avíen de cantar en la dicha eglesia, si la eglesia se cantasse, çinco mille quinientos çinco maravedís et terçia, et ordenaron et mandaron que destos tomassen quatro mille maravedís, et los mille quinientos çinco maravedís et terçia que fincan que fuessen para cantar la capellanía dell alva et otras, segund las ordenare cantar el cabilldo.

Otrossí fallaron que de las capellanías de antanno que non se cantaron en la eglesia de Cuenca, que podíen tomar para esto mille maravedís, et ordenaron et mandaron que fuessen para esta paga estos dichos mille maravedís.//11 . 
Otrossí ordenaron que de los vestiarios de Alarcón et de Moya dell anno primero siguiente que se deven rendar en la era de sessenta et ocho, por la fiesta de la Trinidat primera que viene, et se deven pagar a la dicha fiesta en la era de sessenta et nueve, se tonme para esto quatro mille maravedís, de los vestiarios de Moya mille maravedís et de los vestiarios de Alarcón tres mille maravedís, et entre las otras condiçiones que se an de poner en la dicha renda de los dichos vestiarios que sean éstas de las prinçipales: que los arrendadores de los dichos vestiarios, quier de Alarcón, quier de Moya, sean tenudos de pagar los dichos quatro mille maravedís, los arrendadores de los vestiarios de Alarcón los tres mill maravedís et los arrendadores de los vestiarios de Moya los mille maravedís a la fiesta de Todos Sanctos de noviembre primero que viene, so pena del doblo en nombre de interesse et de los dannos et moscabos que a la eglesia de Cuenca viniere por esta razón.

Otrossí, el dicho Gil Álvarez, arçidiano de Cuenca, se obligó de pagar para esta dicha paga, sin lo que desusso se contiene, mille maravedís.

Suma que monta esto sobredicho, desde la otra postrimera suma fasta aquí, sin los mille maravedís del tiempo de Sancho Martínez, refitorero, que fincan en dubda, segund dessuso está sennalado, veynte et un mille seyçientos et çinquanta maravedís.

Suma que monta todo esto que dicho es que acordaron que se devíe recabuar et pagar para la paga sobredicha, quarenta et un mille quinientos sessenta et nueve maravedís.//11v.

Et fincan que an a dar cuenta Matheo Pérez, canónigo et Savastián Pérez et Miguel Pérez, obrero, de los dineros que envió ell obispo de Évora, segund dicho es, Iseyçientos maravedís/ ${ }^{\mathrm{n}}$ de mille et seyçientos maravedís.

Otrossí, a de dar cuenta Sancho Martínez, refitorero, de lo que finca en él del tiempo que fue refitorero, por los dos mille maravedís que fincan en dubda, segund dessusso se contiene.

Sobresto, después de muchos tractados que ovieron en muchos cabilldos que fizieron fasta martes, treynta días de enero, era de mille trezientos sessenta et ocho annos, que commo quiere que es costumbrado que el cabilldo se llegue en la eglesia de Cuenca a son de la campana mayor, segund es uso et costumbre, pero porque este fecho era muy granado et tannía a muchos, que este dicho día martes, fuessen todos llamados por

n Tachado. 
Estevan Pérez, portero de la eglesia de Cuenca, [et] Pero Martínez, sochantre, notario público de la dicha eglesia, con testigos, et fueles denunçiado por un escripto seellado et so scripto del seello et del nombre del Idicho/ ${ }^{\circ}$ deán Ferrand Garçía, antel dicho notario et testigos, el qual escripto dizíe assí:

Oy, martes, treynta días de enero, era de mille trezientos sessenta et ocho annos, fue acordado por el deán et el cabilldo de la eglesia de Cuenca que para quitar la eglesia del debdo et de la sentençia en que está por lo que deve a la cámara del papa, que commo quier que por la campana se llega el cabilldo de la eglesia de Cuenca, porque lo sepan todos que el cabilldo de tras otro día luego siguiente, postrimero día del dicho $/ / 12 r$ mes, se deve llegar por son de la campana para poner este fecho en tal estado et en tal cabo et por tal acuerdo que non pueda seer renovado, más que sea valedero et estable para en todo tienpo, et esto que sea assí en martes denunçiado a los que son en la çibdad et en las casas de los otros por Estevan Pérez, portero, ante Pero Martínez, notario de la eglesia, et de los otros testigos. Et fueron llamados, segund dessusso se contiene: Ferrand Garçía, deán, Gonçalo Garçía, canónigo, Pero Sánchez, Remir Sánchez e Sancho Sánchez, companneros. Testigos: Garçi Pérez, Martín Sánchez, Martín López, capellanes. Nicolás López, arçidiano de Alarcón. Testigos: Pascual Sánchez, racionero, et Martín Sánchez, capellán. Matheo Pérez, canónigo. Testigos: Martín Sánchez et Pero Martínez, capellanes. Garçía Martínez, canónigo. Testigos: Johán Gutiérrez, canónigo, et Martín Sánchez, capellán. Johán Martínez, raçionero. Testigos: Martín Sánchez et Gil Martínez, canónigo. Johán Martínez, tesorero, Sancho Martínez et Pero Viceynte, canónigos, et Johán Ferrández, compannero, que estavan con él. Testigos: <Pero Martínez, clérigo de Sancta Cruz, et Pero Martínez, criado dell arçipreste, Pero Sánchez, compannero> P, Martín Sánchez et otros. Garçi Domínguez, compannero. Testigos: Sancho Garçía et Johán Garçía, capellanes. Ferrand Garçía, racionero, et Savastián Pérez, compannero. Testigos: Pero Martínez, clérigo de Sancta Cruz, et Pero Martínez, criado dell arçipreste. Pero Sánchez, compannero. Testigos: Ferrand Garçía, raçionero, et Savastián Pérez, compannero. Sancho Pérez, canónigo, que non era en Cuenca, ante las puertas de su casa, et Bernardo Pérez et Ferrand Pérez, raçionero. Testigos: Pero Martínez, sochantre, et Martín Sánchez, capellán. Sancho López, arçidiano de Moya, que non era en Cuenca, ante las

Entre renglones.

Tachado. 
puertas de su casa, Itestigos/ 9 , let/ ' Pascual Sánchez, raçionero. Testigos: Martín Sánchez, capellán, et Johán Yenegrez, escudero. Ruy López, arçidiano de Huepte, ante la puerta de su casa, Ferrand //12v Martínez, compannero, a la puerta de su casa. Testigos: Martín Sánchez et Sancho Garçía. Garçi Ximenez, canónigo. Testigos: Martín Sánchez et Pascual Pérez el Texedor. Guillem Vidal, maestrescuela, ante la puerta de su casa, et Sancho Domínguez, chantre, ante la puerta de su casa, Sancho Gil, racionero. Testigos: Martín Sánchez e Sancho Garçía, los sobredichos. Johán Pérez, arçipreste. Testigos: Martín Sánchez e Pascual Pérez, texedor, sobredichos.

Miércoles, postrimero día del dicho mes de febrero s, era susodicha, llegado el dicho cabillo a son de la dicha campana mayor, segund es uso et costumbre de la dicha eglesia, et seyendo presentes personas et canónigos, los que aquí dirá:

Del coro dell obispo

Gil Álvarez, arçidiano de Cuenca

Johán Martínez, tesorero

Matheo Pérez

Caçinimico

Pero Viceynte

Gonçalo Garçía

Garçi Ximénez
Del coro del deán

Ferrand Garçía, deán

Garçí Martínez

Johán Pérez, arçipreste

Sancho Martínez

Et raçioneros et companneros et canónigos estravagantes que fueron llamandos para esto, segund dessusso se contiene, fizieron leer et examinar este libro et todas las cosas que en él se contienen et cada una dellas, et fallaron por acuerdo, todos de una voluntad, que era muy grand serviçio de Dios et grand pro desta eglesia que todas las cosas sobredichas, et cada una $/{ }^{13 r}$ dellas, se pusiessen en buena execuçión et se cumpliesen en todo, segund dicho es, porque la eglesia salliesse del mal estado en que está, pero tovieron por bien et acordaron que el lprimer día/ término del primer día de Quaresma et de mediada Quaresma a que deven pagar los que sacaron los fructos de los dichos benefiçios por la dicha al-

\footnotetext{
Tachado.

Entre renglones.

Se trata de un error del copista por enero.

Tachado.
} 
moneda, que quanto a los que son benefiçiados en la eglesia de Cuenca et deven pagar algo para esta debda por esta razón o por otra, que quanto a los dichos benefiçiados que se contiene o non se contiene en la dicha carta que enviaron all obispo, que se alongasse fasta el día de Pascua Florida primera que viene, et el deán, con acuerdo de todo el cabilldo, alongó el dicho término fasta el dicho día de Pascua, fincando en su estado las sentençias et las otras cosas sobredichas, et acordaron todos de una voluntad <de una voluntad>, que todos en uno, o cada uno por sí, que fiziessen todo su poder porque todas estas cosas et cada una dellas se cumpliessen. Et cada uno de los sobredichos, perssonas et canónigos, juraron a Dios tanniendo corporalmente los Evangelios, teniendo el libro de los Evangelios Savastián Pérez, compannero de la eglesia de Cuenca, seyendo presentes Pero Martínez, notario público de la eglesia de Cuenca, et otros testigos que para esto fueron llamados, de non mundar nin revocar en ningún tiempo, de dicho o de fecho, las cosas que en este libro se contienen o qualquiere dellas, salvo ende si non fuesse en mejoramiento deste fecho, et desto juraron cada uno por sí. Et se $/ /^{13 v}$ gund dicho es, todos en uno, acabadamente por cabilldo, fizieron su procurador a Ferrand Garçía, deán sobredicho, que fiziesse essa misma jura en boz et en nombre de todo el cabilldo, et luego el dicho deán, teniendo el dicho libro el dicho Savastián Pérez, ante los dichos notario et testigos, en nombre et en boz de todo el cabilldo et de los que son o que fueren daquí adelante, que fazen o fizieren o pudieren fazer cabilldo de la eglesia de Cuenca, o de la mayor et de la más sana parte dellos et en sus almas, juró a Dios et a los sanctos Evangelios, por él corporalmente tanidos, de non mudar nin revocar ninguna cosa de las sobredichas, o qualquiere dellas, en ningún tiempo, si non fuesse en mejoramiento deste fecho. Et por mayor firmeza acordaron que de todo esto que se fiziesse este libro en que escrivieron sus nombres en cabo dél Vas/ "personas et canónigos sobredichos, et mandáronlo seellar con el seello del cabilldo pendiente, et mandaron a Pero Martínez, sochantre et notario sobredicho, que lo signasse de su signo, et por guardar memoria para en siempre que fuesse puesto en el thesoro de la eglesia.

El qual libro fue fecho et acabado et seellado, segund dicho es, et puesto en el tesoro, jueves, ocho días del dicho mes de febrero, era de mille trezientos sessenta et ocho annos.

Decanus (rúbrica).- Archidiaconus conchensis (rúbrica).-Matheus Petri,canonicus (rúbrica).- Johán Martínez (rúbrica).- Garçi Martínez (rú-

¿ Entre renglones. 
brica).- Johanes Petri, archipresbiter (rúbrica).- Ego Caçanimicus, concedo hoc (rúbrica).- En Pero Viçente (rúbrica).- Gonçalo Garçía (rúbrica).Garçía Ximen (rúbrica).- Sancho Martínez (rúbrica).//14r.

Et yo, Pero Martínez, canónigo, sochantre et notario público por actoridat del mucho onrrado padre sennor don Oddo, obispo de Cuenca, et del deán et cabilldo dessa misma, me açerté a todo esto sobredicho que en este libro se contiene, et sennaladamente a prometimiento et jura que los dichos personas et canónigos fizieron cada uno por sí et de sí al poder que el dicho cabilldo dieron al dicho Ferrand Garçía, deán, et a la jura que el dicho Ferrand Garçía, deán, fizo assí commo procurador del dicho cabilldo, segund dessuso se contiene. Et de otro libro que el deán et el cabilldo mandaron fazer sobre este fecho, fiz sacar et escrevir este libro en treze fojas et media deste dicho libro, et pus en cada foja de las sobredichas mi nombre, et vilo so screvir de los sobredichos que desuso se contiene, et seellar del seello del dicho cabilldo, et mandar guardar et poner en guarda a memoria por siempre en el tesoro de la dicha eglesia. Et seyendo presentes Ferrand Garçía, Ferrand Pérez et Pascual Sánchez, raçioneros, Pero Sánchez, Remir Sánchez, companneros, et otros que se açertaron conmigo a lo conçertar et a todo lo sobredicho, testigos que fueron para esto llamados et rogados, fiz escrevir este dicho libro, et a mandamiento de los dichos deán et cabilldo tornelo en pública forma, et en testimonio de verdat cerrelo en la postrimera foja que es en la otra meytad en acabamiento de la catorzena foja deste dicho libro, fincando soberanas et por escrevir diez fojas deste dicho libro. Et pus aquí este mi signo en testimonio de verdat, en el lugar, día, mes e anno sobredicho.(Signo). $/ /^{14 v}$.

\section{(Addendas)}

Viernes, XIII días de abril, era de mill $C C^{\circ s} L X$ et ocho annos, el deán et el cabilldo dieron et entregaron a Matheo Pérez et a Sancho Martínez, canónigos, reçeptores de los dineros que se an de pagar para quitar la eglesia, a una parte quatro mille maravedís de los que envió el obispo de Évora, a otra parte trezientos et XX maravedís que pagó Johán Martínez, thesorero.

Este día dicho entregaron a Gil Álvarez, arçidiano de Cuenca, que arrendó este día mismo las debdas que perteneszen en qualquier manera al cabilldo de los fructos del obispado, de Huepte et de Uclés, por çiento et ochenta florines de oro, tres anielos de oro, el uno de un çafir llano et el verdugo redondo, et otro de çafir redondo et el verdugo llano, et otro de una topeza et el verdugo de tres esquinas, en un cordón de seda cárdena et embueltos en un panno de lino et metidos en una bolsa de marromaque en un cordón de seda bermeja. Otrossí un espada en una vayna arangada 
con contera et tres chapas et arras de plata con una piedra jaspe [con] dizeocho botones en derredor, con una çinta de seda cárdena con $\backslash \mathrm{dos} /{ }^{\vee}$ tres cabos et dos chapas et finiella et quatro ogetes de plata en una funda de cordován prieto en una çinta vaccaria bermeja, que estavan a pennos por los dichos debdos en el dicho sagrario. Et el dicho arçidiano obligó assí et a todos sus bienes de sacar et redrar en todo tiempo, sin danno, de qui quiere que demandasse los dichos anillos et espada al dicho cabilldo o a otri qualquiere por ello, et a esto fueron presentes personas et canónigos que aquí pusieron sus nombres. Testigos que vieron todo esto: Ferrand Garçía, Ferrand Pérez, Sancho Gil, Johán Martínez, raçioneros; Johán Gil, Pero Sánchez, Savastián Pérez, Garçí Domínguez, Ferrand Martínez, companneros; Miguel Pérez, Pero Martínez, sochantre, canónigos extravagantes; Alfonso Martínez, fijo de Pascual Sánchez.

Ferrand Garçía, decanus (rúbrica).- Egidius Aluari, archidiaconus conchensis (rúbrica).- Matheus Petri, canonicus (rúbrica).- Garçi Martínez (rúbrica).- Yo, Johán Pérez, arçipreste (rúbrica).- Johán Martínez (rúbrica).Ego, Caçanimicus, canonicus (rúbrica).- Sancho Martínez (rúbrica).- Garçía Ximénez (rúbrica).

Et yo, Pero Martínez, canónigo, sochantre et notario público, fuy presente a todo lo susodicho. 